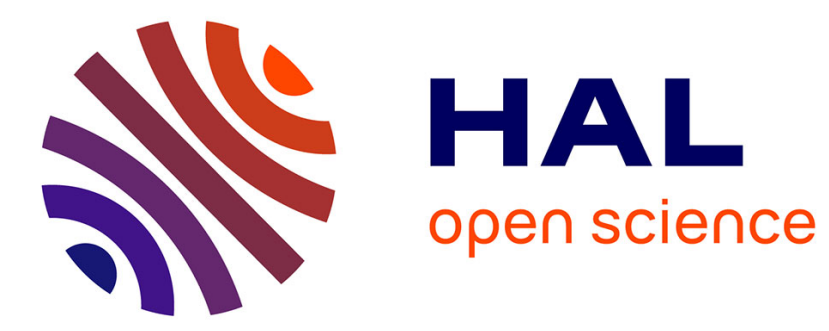

\title{
Hydroclimate change in subtropical South Africa during the mid-Piacenzian Warm Period
}

Xueqin Zhao, Andreas Koutsodendris, Thibaut Caley, Lydie Dupont

\section{To cite this version:}

Xueqin Zhao, Andreas Koutsodendris, Thibaut Caley, Lydie Dupont. Hydroclimate change in subtropical South Africa during the mid-Piacenzian Warm Period. Quaternary Science Reviews, 2020, 249, pp.106643. 10.1016/j.quascirev.2020.106643 . hal-02989245

\section{HAL Id: hal-02989245 \\ https://hal.science/hal-02989245}

Submitted on 5 Nov 2020

HAL is a multi-disciplinary open access archive for the deposit and dissemination of scientific research documents, whether they are published or not. The documents may come from teaching and research institutions in France or abroad, or from public or private research centers.
L'archive ouverte pluridisciplinaire $\mathbf{H A L}$, est destinée au dépôt et à la diffusion de documents scientifiques de niveau recherche, publiés ou non, émanant des établissements d'enseignement et de recherche français ou étrangers, des laboratoires publics ou privés. 


\section{Hydroclimate change in subtropical South Africa during the}

\section{Mid-Piacenzian Warm Period}

3 Xueqin Zhao ${ }^{1}$, Andreas Koutsodendris ${ }^{2}$, Thibaut Caley ${ }^{3}$, Lydie Dupont ${ }^{1}$

41 MARUM - Center for Marine Environmental Sciences, University of Bremen, 5 Leobener Straße, D-28359 Bremen, Germany

$62{ }^{2}$ Institute of Earth Sciences, Heidelberg University, Im Neuenheimer Feld 234-236, D-

769120 Heidelberg, Germany

${ }^{3}$ EPOC, UMR 5805, CNRS, University of Bordeaux, Pessac, France

10 Abstract

11 The mid-Piacenzian Warm Period (mPWP, 3.264-3.025 Ma) of the Pliocene epoch has

12 been proposed as an analog for future climate scenarios. Disagreement between the

13 paleoenvironmental reconstruction and model simulations of the climate in subtropical

14 regions for this period suggests that more investigation of the subtropical climate variability of the mPWP is needed. This study presents pollen, microcharcoal and benthic foraminifera oxygen isotope records generated from marine sediment cores of

17 International Ocean Discovery Program (IODP) Exp. 361 Site U1479 from the Cape

18 Basin offshore of South Africa for the period between 3.337 and 2.875 Ma. With an average sample resolution of $3 \mathrm{ka}$, this record represents the highest-resolution record of mPWP vegetation change from the region. Our results indicate that the vegetation

21 during the mPWP was dominated by fynbos (species-rich heathy vegetation in the

22 Cape Floristic Region) with variable proportions of Ericaceae. Moreover, the 23 development of the Afrotemperate forest (tall, multilayered indigenous forests in South 
24 Africa) reflects shifts in the amounts of precipitation between winter and summer in the 25 year-round rainfall zone. The vegetation variation is probably influenced by the 26 latitudinal insolation gradient in response to precession forcing. Several glacials 27 depicted by the benthic foraminifera oxygen isotope record were characterized by 28 lower percentage values of Restionaceae, higher percentage values of ericoid fynbos 29 and Afrotemperate forest. These events correspond well with cooler SE Atlantic sea 30 surface temperatures driven by interactions of both atmospheric and oceanographic 31 processes. The cooler sea surface temperatures attributed to Antarctic ice sheet 32 expansion, reduced Agulhas leakage (heat and salt transfer from the Indian Ocean to 33 the Atlantic Ocean) and/or intensified southern Benguela upwelling, resulted in less 34 precipitation in the winter rainfall zone of South Africa.

35 Keywords: Vegetation, hydroclimate, mid-Piacenzian Warm Period, IODP Site U1479, 36 South Africa 


\section{Introduction}

The mid-Piacenzian (mid-Pliocene) Warm Period (mPWP, 3.264-3.025 Ma) of the Pliocene epoch was the most recent period in geological history in which global climate was warmer than today as depicted by both paleoclimate data and modelling studies (Haywood et al., 2013). During that period, paleogeography, paleoceanography and paleobiology were the same or very similar to the modern situation (Crowley, 1996) making the mPWP a suitable analog for future climate scenarios (Haywood et al., 2009, 2013). On this basis, the mPWP has become the focus of comparative and detailed numerical climate modelling and data/model comparisons. The simulated global temperatures during the mPWP were approximately $2-3^{\circ} \mathrm{C}$ higher than today (Haywood and Valdes, 2004) and atmospheric $\mathrm{CO}_{2}$ concentrations (between 330 and 400 parts per million) were estimated to be 50-120 ppm higher than pre-industrial levels (275-285 ppm) and probably close to today's level (Pagani et al., 2010). Average global sea level was 10-40 m higher than today (Raymo et al., 2011), the extent of continental ice sheets was limited (Dolan et al., 2011), and the Atlantic meridional overturning circulation (AMOC) was comparable to or stronger than during pre-industrial times (Raymo et al., 1996).

However, it remains unclear what mechanisms drove the amplification of warm conditions during the mPWP. Previous studies including paleoclimate modelling, micropaleontological paleotemperature records and paleo- $\mathrm{CO}_{2}$ estimates based on the boron isotopes of planktic foraminifers, have focused on the role of the atmosphere and oceans, in particular that of ocean-atmospheric $\mathrm{CO}_{2}$ levels and changes in the meridional ocean heat flux (Bartoli et al., 2011; Dowsett et al., 1992; Rind and Chandler, 1991). Later studies, however, suggest additional drivers of the warmer Pliocene conditions independently or in combination with $\mathrm{CO}_{2}$ concentration variations 
62 (Haywood et al., 2009). Salzmann et al. (2008) proposed that the potential causes for the MPWP have only been partially identified. These causes may relate to a combination of changes in orography, atmospheric $\mathrm{CO}_{2}$ concentrations, water vapor content, ocean circulations and ocean heat transport (Crowley, 1996; Lunt et al., 2012; Raymo et al., 1996), which in turn affect changes in sea-ice cover, surface albedo, cloud cover and temperature (Haywood and Valdes, 2004).

Although the climate of the middle Pliocene is relatively stable compared to the Quaternary, it does display climate variability on orbital timescales (Lisiecki and Raymo, 2005), which can be interpreted to represent glacial-interglacial periods (Lunt et al., 2012). Just prior to the mPWP, the middle Pliocene was interrupted by a short intense global glaciation (3.305-3.285 Ma) during marine isotope stage M2 (MIS M2) (Lisiecki and Raymo, 2005), which may be seen as a premature step of the climate system in establishing an ice age world (De Schepper et al., 2009; Prell, 1984). The mPWP encompasses six interglacials and glacials including the glacial MIS KM2. Earlier studies compared separately modelled interglacials within the mPWP. The results show that different orbital boundary conditions lead to considerable differences in simulated climate and vegetation between the warm stages (Prescott et al., 2018).

We collected summarized paleovegetation studies of the middle and late Pliocene based on pollen or carbon isotopic composition of pedogenic carbonate and mammal teeth. The results show consistency with modern vegetation (Figure 1), however, due to the lack of records in the southern hemisphere, it should be interpreted with caution. Many paleoclimate studies indicate that the vast northern and southern subtropical regions were wetter during the Miocene and Pliocene with a spread of tropical savannahs and woodland where subtropical deserts and arid regions exist today (Salzmann et al., 2008), in particular in Africa (Levin, 2015) and Australia (Martin, 2006). 
However, most models predict drier conditions during past warm climates including the warm Pliocene (Lau et al., 2013). This puzzle is explained by weaker atmospheric circulation in response to reduced meridional and zonal temperature gradients (Burls and Fedorov, 2017).
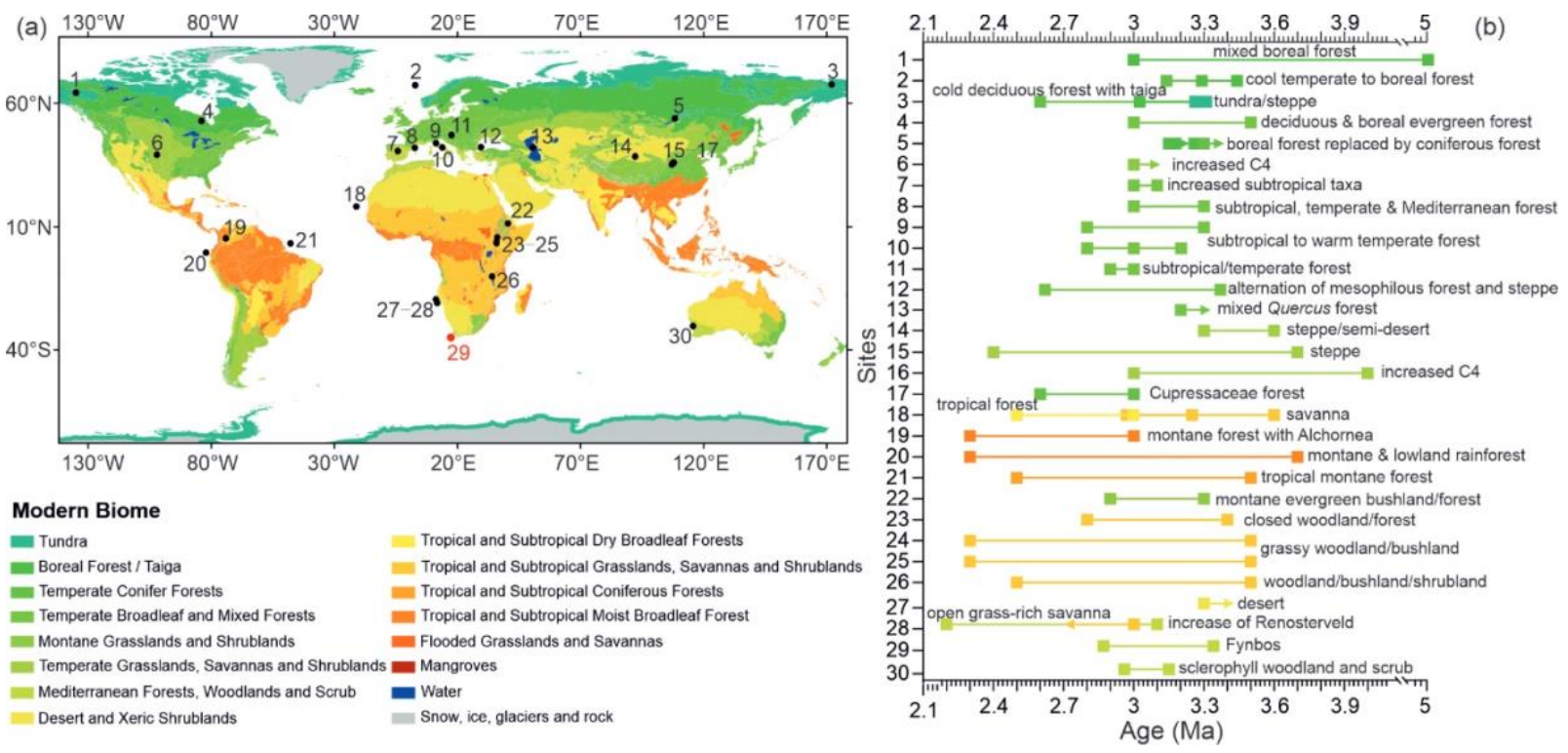

Modern Biome

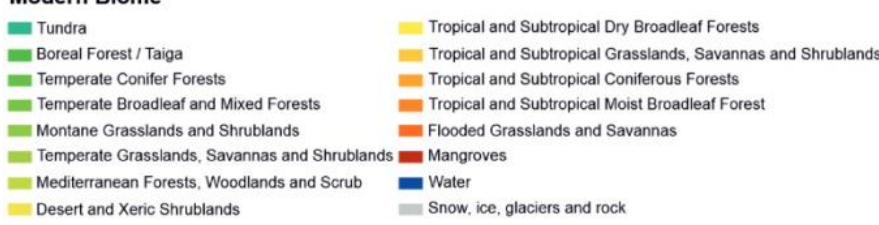

Figure 1. Modern biomes (a) and paleovegetation records between 5 and $2.2 \mathrm{Ma}(\mathrm{b})$. The colors in (b) correspond to the modern terrestrial biomes which are derived from the World Wildlife Fund (WWF) ecoregions depicted in (a). The Y-axis "Sites" in (b) corresponds to the numbers in (a). Detailed data sources of (b) can be found in Supplementary file 1.

Southern Africa has experienced strong regional differences in moisture availability (Chase and Meadows, 2007; Zhao et al., 2016b) due to the interactions of both atmospheric and oceanic circulations between the South Atlantic, Indian and Southern Oceans. The combination of palynological, geomorphological and sedimentological evidence indicates warm mesic conditions in southern Africa during the mid-Pliocene

101 (Scott and Partridge, 1994). A mixture of shrubland (fynbos), woodland and forest 102 prevailing in South Africa during the mid-Pliocene suggests more humid conditions 103 (Salzmann et al., 2008). On the other hand, the model study by Prescott et al. (2018) 104 infers dominance of shrubland and desert instead of forest and woodland in South 105 Africa during all four mPWP interglacials (G17, K1, KM3 and KM5c). Moreover, other 
106 models also predict less annual rainfall and less winter rainfall for Pliocene South Africa

107 (Hunter et al., 2019). First data-model comparisons (the Pliocene Model 108 Intercomparison Project Phase 2; PlioMIP2), mainly concerning sea surface

109 temperatures, have been carried out (Haywood et al., 2020, accepted). The results 110 show significant agreement between simulated and reconstructed temperature change 111 although with notable local signals of data/model disagreement occurring in the 112 Benguela upwelling system. The large data/model discrepancy in the Benguela 113 upwelling system is also observed in SST anomalies focusing on MIS KM5c (3.205 Ma)

114 (the warmest phase of the mPWP), which might be accounted for by a combination of 115 displaced upwelling and warm upwelled water (McClymont et al., 2020). These data116 model mismatches indicate that more detailed mPWP hydroclimate reconstructions of 117 subtropical regions are needed, especially in the southern hemisphere where well118 dated high-resolution Pliocene paleorecords are scarce. As such, a new record from 119 the South African Cape region at the intersection of the different atmospheric and 120 oceanic systems between the South Atlantic, Indian and Southern Oceans is essential 121 to fill in a gap of information on the southern hemisphere subtropical regions. Thus, to 122 better understand the hydroclimate of subtropical southern Africa during the mPWP, 123 we produced a continuous high-resolution pollen, microcharcoal and benthic 124 foraminifera oxygen isotope record from marine sediment cores of IODP Exp. 361 Site $125 \mathrm{U} 1479$ for the period between 3.337 and 2.875 Ma at millennial-scale resolution (ca. 3 126 ka) (Figure 2). The aim of our study is to assess the variability of vegetation and climate 127 changes in southernmost Africa during the mPWP and to determine possible driving 128 mechanisms. 


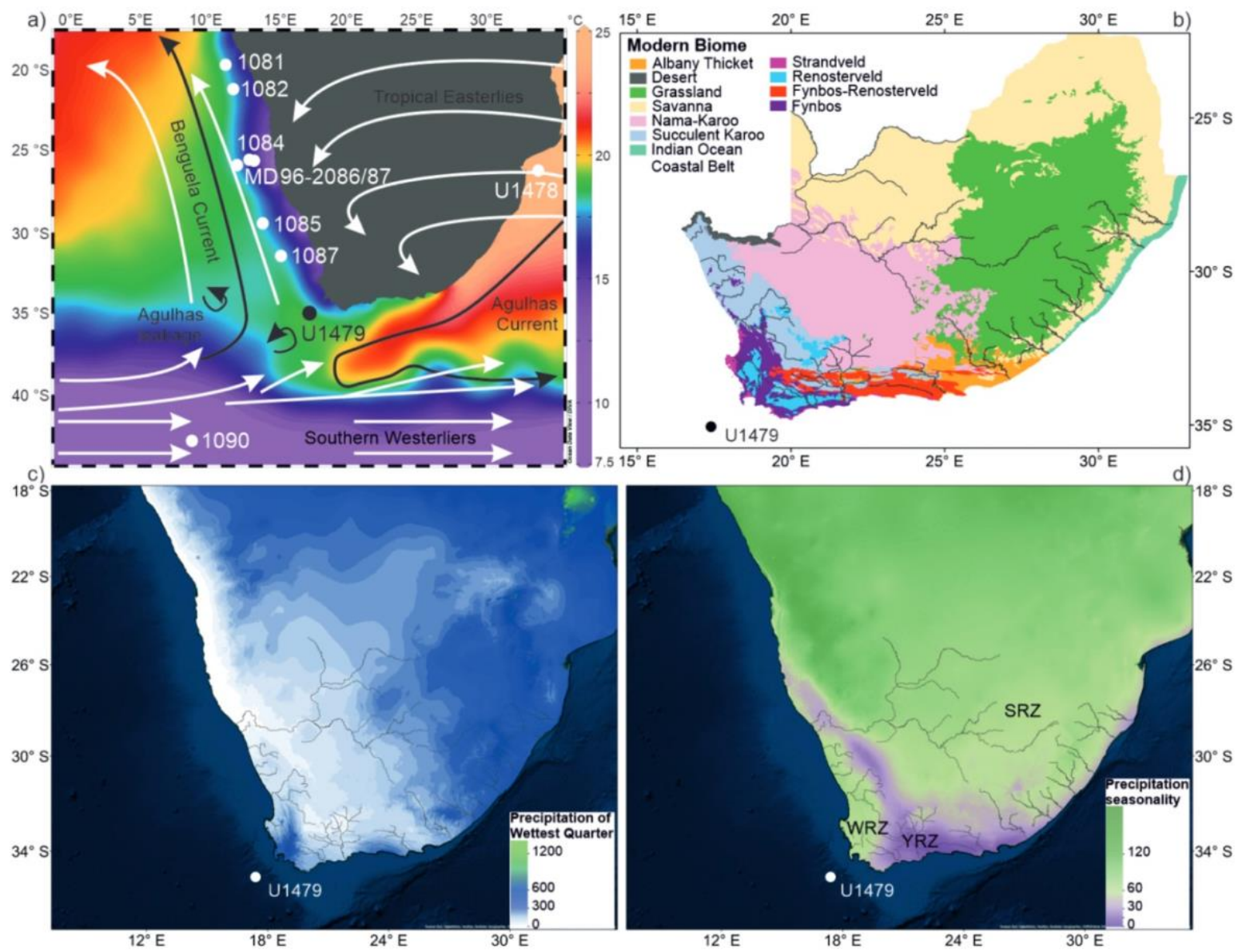

130 Figure 2. (a) Map of modern atmospheric and oceanic circulations with modern sea surface 131 temperatures (World Ocean Atlas 2013) and the location of IODP Site U1479 and the other sites 132 discussed in this study. (b) Modern vegetation of South Africa with main rivers draining to the ocean 133 (Mucina and Rutherford, 2006). Modern precipitation of wettest quarter (c) and precipitation seasonality 134 (d) showing three different rainfall zones in southern Africa derived from WorldClim version 1.3 (Hijmans 135 et al., 2005). Winter rainfall zone, WRZ, at the southwestern tip of the continent which receives over $66 \%$ 136 of annual rainfall between April and September; year-round rainfall zone, YRZ, which receives both 137 winter and summer rainfall throughout the year (purple); summer rainfall zone, SRZ, in the rest of the 138 subcontinent which receives over $66 \%$ of annual rainfall between October and March.

\section{Regional setting}

\subsection{Climate and oceanic circulation}

141 Modern climate of southern Africa is controlled by the position and strength of the 142 South Atlantic and the Indian Ocean anticyclones (Shannon and Nelson, 1996) (Figure 
143 2), which results in three different rainfall zones from west to east of South Africa:

144 winter rainfall zone (WRZ), year-round rainfall zone (YRZ) and summer rainfall zone

145 (SRZ) (Tyson and Preston-Whyte, 2000). The pressure difference between the South

146 Atlantic anticyclone and the continental pressure field causes alongshore southeast

147 trade winds (SE trade winds). The SE trade winds drive an offshore, surface-drift

148 inducing Benguela upwelling causing aridity in western southern Africa north of the

149 Cape region. In the Cape region, moisture is mainly supplied by the southern westerlies

150 during austral winter. The northern part of the WRZ is relatively arid due to the all-year

151 influence of the cold waters of the Benguela upwelling system. The influence of

152 westward to south-westward directed offshore winds (known as Berg winds) is very

153 limited because they are blocked by the southern westerlies and almost no dust plumes

154 can be observed south of $28^{\circ} \mathrm{S}$ (Eckardt and Kuring, 2005). The SRZ receives most of

155 its rainfall from tropical moisture easterlies during austral summer. In contrast to the

156 pronounced seasonality in the $\mathrm{WRZ}$ and SRZ, an intermediary area between them is

157 the YRZ influenced by the interaction of both temperate and tropical circulation

158 systems. In the YRZ, at least 11 but mostly all 12 months of the year contribute $5 \%$ or

159 more to the long-term average of the total annual rainfall during 1979-2011

160 (Engelbrecht et al., 2015).

161 Rainfall amounts, seasonality and distribution patterns in southern Africa are further

162 influenced by two major oceanic circulation systems (Figure 2). One is the northward 163 flowing Benguela Current (BC) along the west coast of southern Africa, the other is the 164 Agulhas Current (AgC) (Nelson and Hutchings, 1983; Shannon and Nelson, 1996). At

165 the southern boundary of the Benguela upwelling system, the relatively cool and

166 oligotrophic waters of the South Atlantic Current and the cold waters of the Antarctic

167 Circumpolar Current meet the south-westward flowing warm and saline waters of the

168 Agulhas Current. Most of the $\mathrm{AgC}$ waters are retroflected to the south and east forming 
169 the Agulhas Return Current, while a small part of the AgC continues in a north-westerly

170 direction through the South Atlantic Ocean in the form of eddies. The leakage is

171 determined mainly by the latitudinal position and intensities of the southern westerlies.

172 During austral summer, the southward contraction and intensification of the southern

173 westerlies would favor more Agulhas leakage, coinciding with aridity in the WRZ

174 (Biastoch et al., 2009; Durgadoo et al., 2013).

175 IODP Exp. 361 Site U1479 is located on the western slope of the Agulhas Bank in

176 Cape Town under the pathway of mixed water masses: southward flowing North

177 Atlantic deep water, cold northward-flowing Benguela Current, warm and salty Agulhas

178 leakage (Hall et al., 2017).

\section{$179 \quad 2.2$ Vegetation and fire}

180 The strong west-east gradient in rainfall amount and seasonality has a great effect on

181 the vegetation resulting in nine biomes in southern Africa (Figure 2) (Cowling et al.,

182 1997; Mucina and Rutherford, 2006). The continental area near the study site is

183 dominated by vegetation types including Fynbos, Renosterveld, Succulent Karoo and

184 Nama Karoo. In addition, small patches of Afrotemperate Forest occur.

185 Subtropical regions are equatorward defined by the transition from subtropical to 186 tropical (monsoonal) climates. The rainfall season changes from summer rains in the

187 tropics to winter rains in the subtropics, which has a large impact on vegetation. In

188 southern Africa, the subtropical winter rainfall zone (Chase and Meadows, 2007) is

189 nowadays restricted to the Western and Southern Cape Province, which is mainly

190 dominated by fynbos (Linder, 2003). Fynbos is a species-rich heathy vegetation,

191 which was established in South Africa during the late Miocene (Dupont et al., 2011).

192 The Fynbos biome, part of the Cape Floristic Region, has extremely high levels of

193 species richness and endemism. It is an evergreen, fire-prone shrubland in the 
194 southwest Cape, which is typified by the presence of restios (wiry, evergreen 195 graminoids of the Restionaceae), a high cover of ericoid shrubs (fine-leaved shrubs of

196 Ericaceae, Asteraceae, Rhamnaceae, Thymelaeaceae and Rutaceae), and the 197 common occurrence of proteoid shrubs (Proteaceae). Rainfall usually varies from 600 198 to $800 \mathrm{~mm} / \mathrm{yr}$. Other important features of fynbos are the presence of leaf spinescence, 199 high sedge (Cyperaceae) cover and low grass (Poaceae) cover (Mucina and 200 Rutherford, 2006). Fynbos is found especially along the southwestern and southern 201 coast of South Africa and thus receives most rainfall during austral winter. 202 Renosterveld is an evergreen, fire-prone shrubland or grassland, which is dominated 203 by small, cupressoid-leaved and evergreen asteraceous shrubs (principally 204 renosterbos, Elytropappus rhinocerotis). Other important shrub represented in 205 renosterveld include Boraginaceae, Fabaceae, Malvaceae, Cliffortia and 206 Anthospermum (Goldblatt and Manning, 2002). The Succulent Karoo biome, located 207 in a narrow strip inland of the west coast, is a semidesert region characterized by dwarf 208 leaf-succulents of which Aizoaceae (including Mesembryanthemoideae) and 209 Crassulaceae are particularly prominent; many other families are also common 210 including Asteraceae, Amaranthaceae, Euphorbiaceae (Euphorbia) and 211 Zygophyllaceae (Zygophyllum) (Wheeler, 2010) but grass cover is low. In comparison 212 to the Fynbos biome, the Succulent Karoo biome is better adapted to arid conditions 213 and higher summer temperatures (Carr et al., 2014), receiving most of the rainfall 214 during austral winter. The Nama Karoo biome, which is a semi-desert dwarf and grassy shrubland found on the central plateau, is dominated by Asteraceae, Poaceae, 216 Aizoaceae, Liliaceae and Scrophulariaceae. The Nama Karoo biome located northeast 217 of the study area, receives rainfall mainly during austral summer. The Afrotemperate 218 Forest biome, which is restricted to areas with mean annual rainfall of more than 725 $219 \mathrm{~mm}$ in the SRZ and more than $525 \mathrm{~mm}$ in the WRZ (Mucina and Rutherford, 2006) 
comprises mostly of evergreen trees in multi-layered canopies, while the ground layer

221 is often poorly developed due to the dense shade. The southern Afrotemperate forest occurs in patches near Port Elizabeth in the east to Cape Peninsula in the west along 223 the feet of south and east-facing slopes, and in ravines and deep gorges of the Cape 224 Fold Belt mountains (Bergh et al., 2014). These forests reach their greatest extent in 225 the southern Cape along the narrow (ca. $250 \mathrm{~km}$ long) coastal strip between 226 Humansdorp in the east to the west of Mossel Bay (Bergh et al., 2014).

227 Fire is important in the fynbos ecosystem, which burns on a 5-50 year rotation, usually 228 in the order of 15-25 years (Mucina and Rutherford, 2006). Fire regimes in 229 Renosterveld are largely unknown; it is however assumed that fire rotation lies within 230 a 2-10 year range. Presently, fires occur in late summer and early autumn, towards 231 the end of the dry season naturally due to sparks of rockfalls and lightning (Bond, 1996; 232 Van As et al., 2012).

233 The YRZ also plays an important role in fostering the extraordinary botanical diversity 234 of the region (Mucina and Rutherford, 2006; Bergh et al., 2014). In the southern Cape 235 region, there is a mosaic of various vegetation types of fynbos as well as Afrotemperate 236 forest and coastal thicket. Generally, Afrotemperate forest patches require the highest 237 values of soil moisture (average annual rainfall varies between 500 and $1200 \mathrm{~mm}$ ) 238 (Mucina and Rutherford, 2006) and are thus most prominent in the valleys, whereas 239 fynbos and coastal thicket occur in the coastal lowlands and dunes (Quick et al., 2018). 240 Afrotemperate forest in this region can be found within the Touws River and Duiwe 241 River valleys which are dominated by Afrocarpus falcatus, Podocarpus latifolius and 242 Olea capensis (Cowling et al., 1997).

\section{3. Materials and methods}


245 The samples investigated in this study were collected from sediment cores of IODP 246 Exp. 361 Site U1479 ( $35^{\circ} 03.52^{\prime} \mathrm{S}, 17^{\circ} 24.03^{\prime} \mathrm{E}, \sim 2630 \mathrm{~m}$ water depth). Site U1479 is 247 located in the Cape Basin on a $30 \mathrm{~km}$ wide morphological high, rising $200 \mathrm{~m}$ above 248 the regional seafloor on the mid to lower western slope of the Agulhas Bank, $\sim 130 \mathrm{~km}$ 249 southwest of Table Mountain and Cape Town, South Africa (Hall et al., 2017). Material 250 from the undisturbed Holes U1479B and U1479C were selected to obtain a complete 251 spliced stratigraphic section from the best core parts using color and natural gamma ray data. The photos of the cores can be found on the IODP website with the following link (http://publications.iodp.org/proceedings/361/EXP_REPT/CORES/IMAGES/). The original meter composite depth was updated to an adjusted, so-called composite depth below seafloor (m CCSF-A). The study interval was first defined based on the shipboard age model, which was developed using bio- and magnetostratigraphy (Hall et al., 2017). The final age model across the study interval was further refined by tuning of benthic foraminifera oxygen isotope curves to the global LR04 benthic $\delta^{18} \mathrm{O}$ stack (Lisiecki and Raymo, 2005) using the AnalySeries software (Paillard et al., 1996) and yielded a correlation coefficient of $R=0.81$ for the studied time interval. It provides a continuous record between 3.337 and $2.875 \mathrm{Ma}$. The sedimentation rates of the investigated interval between 141.24 and 164.07 m CCSF-A lie between 4.1 and 6.8 $\mathrm{cm} / \mathrm{ka}$ (an average of $5.0 \mathrm{~cm} / \mathrm{ka}$ ).

\subsection{Benthic foraminifera $\delta^{18} \mathrm{O}$ analysis}

265 Specimens of benthic Cibicides wuellerstorfi foraminifera were picked from the 250$266315 \mu \mathrm{m}$ size fraction.

26776 samples were measured with a MultiPrep system on line with a dual Inlet

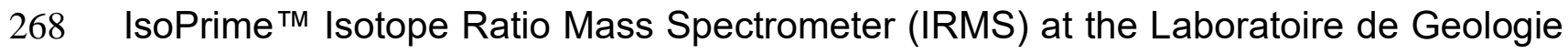
of the University of Lyon. Calcium carbonates were reacted with anhydrous phosphoric 
270 acid at $90^{\circ} \mathrm{C}$ to generate $\mathrm{CO}_{2}$. Isotope compositions are quoted in the delta notation 271 in \%o relative to Vienna Pee Dee Belemnite (VPDB). Isotopic data result from a one272 point calibration using the internal reference 'Carrara Marble' (Analytical standard

273 deviation of $0.05 \%$ for $\delta^{18} \mathrm{O}$ with a carbonate weight $>100 \mu \mathrm{g}$ and $0.1 \%$ with a 274 carbonate weight $<100 \mu \mathrm{g}$ ), itself regularly calibrated against the international reference 275 NBS19.

27617 samples were carried out on a Thermo Scientific 253 Plus isotope ratio mass 277 spectrometer coupled to a Kiel IV carbonate device at EPOC laboratory, University of 278 Bordeaux. The automated preparation system (Kiel IV) transforms solid carbonate 279 samples into $\mathrm{CO}_{2}$ gas by treatment with orthophosphoric acid at a constant 280 temperature of $70^{\circ} \mathrm{C}$. The sample $\mathrm{CO}_{2}$ gas is then transferred using a microvolume, 281 and introduced by dual inlet in the Mass spectrometer to measure its ${ }^{18} \mathrm{O} /{ }^{16} \mathrm{O}$ isotopic 282 ratio in comparison with a calibrated reference gas. Aliquots of NBS19 standard, which 283 is calibrated against the VPDB, were analyzed with the samples to correct any 284 deviation of the reference gas. Oxygen isotopic ratio values are expressed using the $\delta$ 285 notation with a per mil deviation (\%o) from VPDB. Analytical standard deviation is $\approx$ $286 \quad 0.06 \%$ for $\delta^{18} \mathrm{O}$.

287 In three of the samples analyzed in this study no Cibicides wuellerstorfi could be found. 288 We, therefore, analyzed $\delta^{18} \mathrm{O}$ on Uvigerina peregrina taxa in the same size fraction. 289 Because Uvigerina peregrina is isotopically heavier than Cibicides by $0.47 \%$, we 290 adjusted Uvigerina peregrina $\delta^{18} \mathrm{O}$ to the Cibicides scale by subtracting $0.47 \%$ 291 according to Marchitto et al. (2014). Benthic foraminifera $\delta^{18} \mathrm{O}$ are available and stored 292 in the Pangaea database (https://doi.pangaea.de/10.1594/PANGAEA.919576).

\section{3.3 Palynological analysis}


294 A total of 151 samples were taken at $15 \mathrm{~cm}$ intervals between 141.24 and $164.07 \mathrm{~m}$

295 CCSF-A for palynological analysis, aiming at a temporal resolution of ca. $3 \mathrm{ka}$. The samples were prepared with the following steps: 1) determination of the sample volume by water replacement; 2$)$ decalcification with diluted cold $\mathrm{HCl}(\sim 10 \%)$ and addition of Lycopodium spore tablets (12 samples with 2 tablets of batch Nr. 4832162 and the other 139 samples with 2 tablets of batch Nr. 177745); 3) after washing, the samples were treated with cold HF ( 40\%); 4) the samples were shaken for 2 hours, and then kept standing for two days to remove silicates; 5) concentrated $\mathrm{HCl}$ ( 37\%) was added to keep fluor-complexes in solution; 6) all samples were first sieved over a $125 \mu \mathrm{m}$ metal mesh and then sieved over a 7- $\mu$ m nylon mesh screen while ultrasonically disaggregating organic matter; 7) samples were stored in water, mounted in glycerol and examined under a light microscope (magnification $400 \mathrm{x}$ and $1000 \mathrm{x}$ ) for pollen, spores, fresh-water algae, and microcharcoal. Pollen grains were identified using the African pollen reference collection of the Department of Palynology and Climate Dynamics of the University of Göttingen, the African Pollen Database (http://apd.sedoo.fr/pollen/interface/indexPollen.html) and literature (Bonnefille and Riollet, 1980; Scott, 1982). Pollen zonation was conducted by Constrained Incremental

311 Sum of Squares Cluster Analysis (CONISS, TILIA 2.0.41, with dendrogram scale of 312 total sum of squares) including all counted pollen and spore taxa (Figure 3). All pollen and spore taxa were included in the pollen sum (ranging between 145 and 347 with an

314 average of 290 per sample) used to calculate pollen percentages. Pollen concentration 315 was determined based on the Lycopodium spore counts. Samples volumes were measured using water displacement to calculate concentration values. Pollen accumulation rates were calculated by multiplying the pollen concentration ( $\mathrm{grains} / \mathrm{cm}^{3}$ )

318 by the sedimentation rate $(\mathrm{cm} / \mathrm{ka})$ for each sample. The $95 \%$ confidence intervals of percentages were calculated following Maher (1972). All counts of pollen and spores 
321 (https://doi.pangaea.de/10.1594/PANGAEA.919633). Microcharcoal analysis was

322 conducted on the same slides as the pollen analysis using the 202-touch point count 323 method (Clark, 1982) to calculate the microcharcoal concentration in square 324 centimeter/cubic centimeter $\left(\mathrm{cm}^{2} / \mathrm{cm}^{3}\right)$. At least 225 fields per sample were analyzed 325 to improve the statistical reliability of the results. Microcharcoal concentrations are 326 available and stored in the Pangaea database 327 (https://doi.pangaea.de/10.1594/PANGAEA.919575).

\section{$328 \quad 3.4$ Spectral analysis}

329 To analyze cyclicity in the palynological records, we carried out a spectral analysis 330 (window: hanning; oversample: 2; segments: 3 ) using the module REDFIT (Schulz and 331 Mudelsee, 2002) of the paleontological statistics package PAST vs 3.0 (Hammer et al., 332 2001).

333 A cross spectral analysis between pollen groups and southern hemisphere latitudinal 334 winter insolation gradient (LIG) was also carried out with AnalySeries software (Paillard 335 et al., 1996). Linear interpolation was used to resample data and LIG according to the 336 pollen resolution. For each analysis, B-Tukey spectrum was used within a Bartlett

337 window. The time step used for the B-Tukey analysis is 2000 years. The bandwidth is $3381.07 \times 10^{-5}$, non-zero coherence significant at the $95 \%$ confidence level is higher than $339 \quad 0.55$

\section{4. Results}

341 Pollen and spores are relatively abundant and generally well preserved in IODP Site $342 \mathrm{U} 1479$ for the period 3.337 to $2.875 \mathrm{Ma}$. Pollen concentrations range from 289 to 1037 343 grains $/ \mathrm{cm}^{3}$ with an average of 533 grains $/ \mathrm{cm}^{3}$ and pollen accumulation rates range 
344 from $1.2 \times 10^{3}$ to $5 \times 10^{3} \mathrm{grains} / \mathrm{cm}^{2} / \mathrm{ka}$ with an average of $2.7 \times 10^{3} \mathrm{grains} / \mathrm{cm}^{2} / \mathrm{ka}$. The 345 pollen diagram of selected pollen taxa for the period from 3.337 to $2.875 \mathrm{Ma}$ is provided 346 in Figure 3. The most abundant pollen taxa throughout the record are Restionaceae 347 ( 18-44\%, average 33\%), Cyperaceae ( 9-26\%, average 18\%), Tubuliflorae ( 4$34815 \%$, average $9 \%)$, Podocarpaceae ( 1-15\%, average 5\%), Poaceae $(\sim 2-11 \%$, 349 average 6\%). Other common pollen taxa include Stoebe-Elytropappus-type ( 0-7\%, 350 average 2\%), Ericaceae ( 1-8\%, average 4\%), CCA (including Amaranthaceae, and 351 Caryophyllaceae) ( 0-9\%, average $3 \%)$, Cliffortia-type ( 0-3\%, average 0.7\%), 352 Passerina ( 0-3\%, average 0.6\%), Protea-type ( 0-4\%, average 1\%), Phragmitis353 type ( 0-7\%, average $2 \%)$, Artemisia-type ( 0-3\%, average 0.7\%), Anthospermum 354 ( 0-4\%, average 0.8\%), Pentzia-type ( 0-4\%, average $2 \%)$ and Euphorbia ( 0-3\%, 355 average $0.6 \%)$.

356 The identified pollen was grouped into vegetation categories (Figure 4) as ericoid 357 fynbos (including Stoebe-Elytropappus-type, Ericaceae, Cliffortia, Passerina, other 358 Thymelaeaceae, Protea-type), wetland taxa (including Cyperaceae, Phragmites-type, 359 Typha, Haloragaceae), cosmopolitan taxa (including Poaceae, Asteraceae 360 Tubuliflorae, Artemisia-type, Anthospermum, Euphorbiaceae pp), succulent and 361 drought-resistant taxa (including Pentzia-type, Amaranthaceae, Aizoaceae, Euphorbia) 362 and Afrotemperate forest (including Podocarpaceae, Olea-type). This grouping is 363 based on the modern pollen distribution in the Namaqualand mudbelt along the west 364 coast of South Africa (Zhao et al., 2016a, 2016b) and on palynological studies from the 365 Cederberg Mountains (Valsecchi et al., 2013) and the south coast (Quick et al., 2018). 


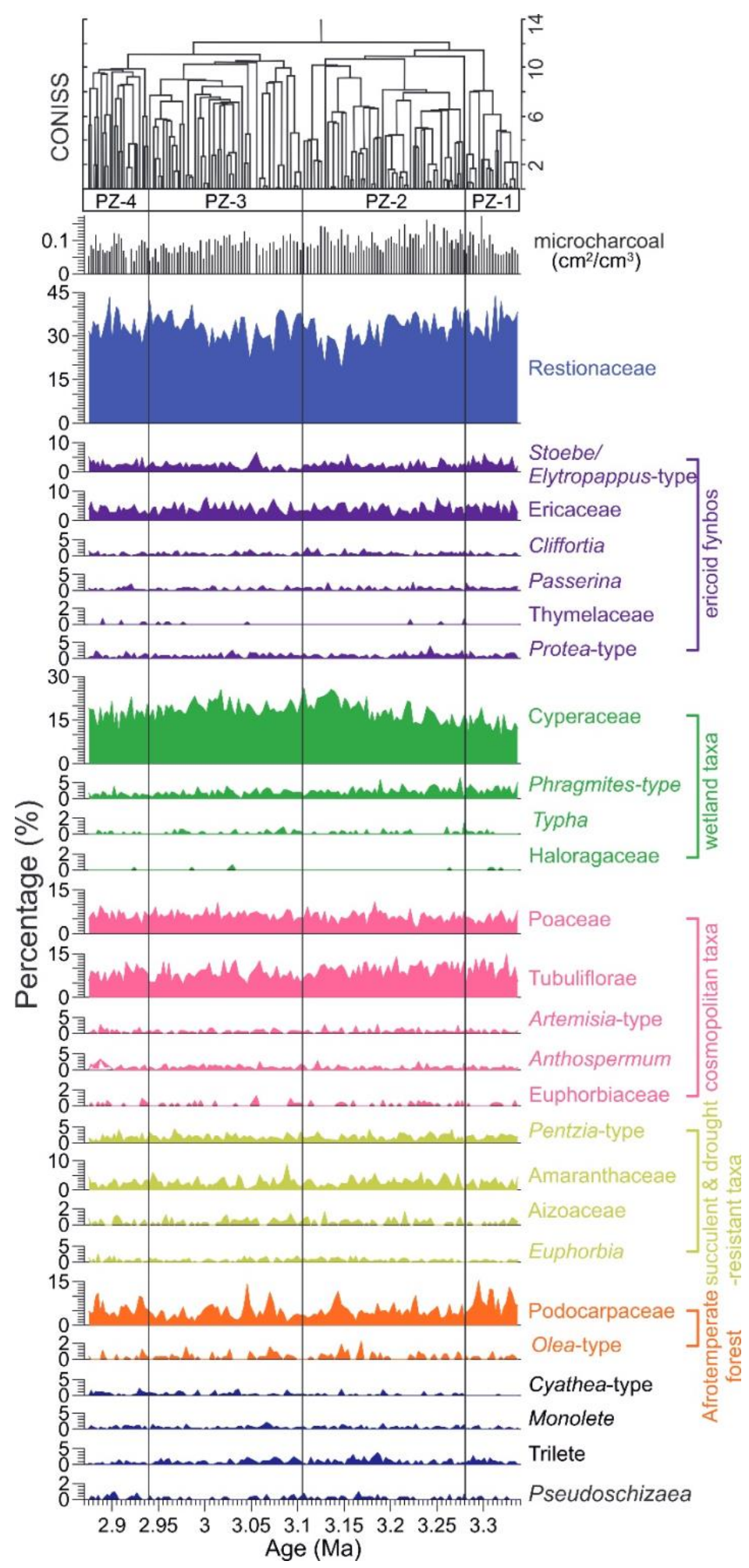

367 Figure 3. Pollen percentages of selected taxa from IODP Site U1479. Pollen assemblage zones were 368 derived by CONISS (Grimm, 2015).

369 The record has been divided into four pollen assemblage zones (PZ) using the 370 CONISS calculation (Grimm, 2015). Zone PZ-1 (3.337-3.280 Ma) is characterized by pollen percentage maxima of Restionaceae, ericoid fynbos and Afrotemperate forest. 
372 The percentages of succulent and drought taxa, and Cyperaceae reach minima in this 373 zone. Zone PZ-2 (3.280-3.107 Ma) is characterized by a pollen percentage decrease 374 of Restionaceae reaching minima around $3.147 \mathrm{Ma}$, while ericoid fynbos reaches high 375 values around the same time. Afrotemperate forest representation has much lower 376 values in PZ-2 than in PZ-1 but shows several peaks. Succulent and drought taxa start 377 to increase to high values between 3.279 and $3.156 \mathrm{Ma}$. This zone is also 378 characterized by the increase of wetland taxa reaching maxima around 3.136 Ma. In 379 zone PZ-3 (3.107-2.941 Ma), the pollen percentage of Restionaceae starts to increase 380 again, while the percentage of wetland taxa fluctuates around relatively high values 381 with slightly decreasing trend. Succulent and drought taxa fluctuate with no clear trend. 382 Zone PZ-4 (2.941-2.875 Ma) shows alternating percentage maxima of Restionaceae 383 and Afrotemperate forest.

384 Microcharcoal concentration values fluctuate between 0.04 and $0.17 \mathrm{~cm}^{2} / \mathrm{cm}^{3}$ with an 385 average of $0.09 \mathrm{~cm}^{2} / \mathrm{cm}^{3}$ (Figure 4). Microcharcoal concentrations are characterized 386 by relatively low values at the beginning of the record with a generally increasing trend 387 until $3.239 \mathrm{Ma}$ and a maximum of $0.17 \mathrm{~cm}^{2} / \mathrm{cm}^{3}$ at $3.298 \mathrm{Ma}$. After $3.239 \mathrm{Ma}$, 388 microcharcoal concentrations start to decline reaching minimum values $\left(0.04 \mathrm{~cm}^{2} / \mathrm{cm}^{3}\right)$ 389 at 2.950 Ma which then increase to higher values again after $2.941 \mathrm{Ma}$. 


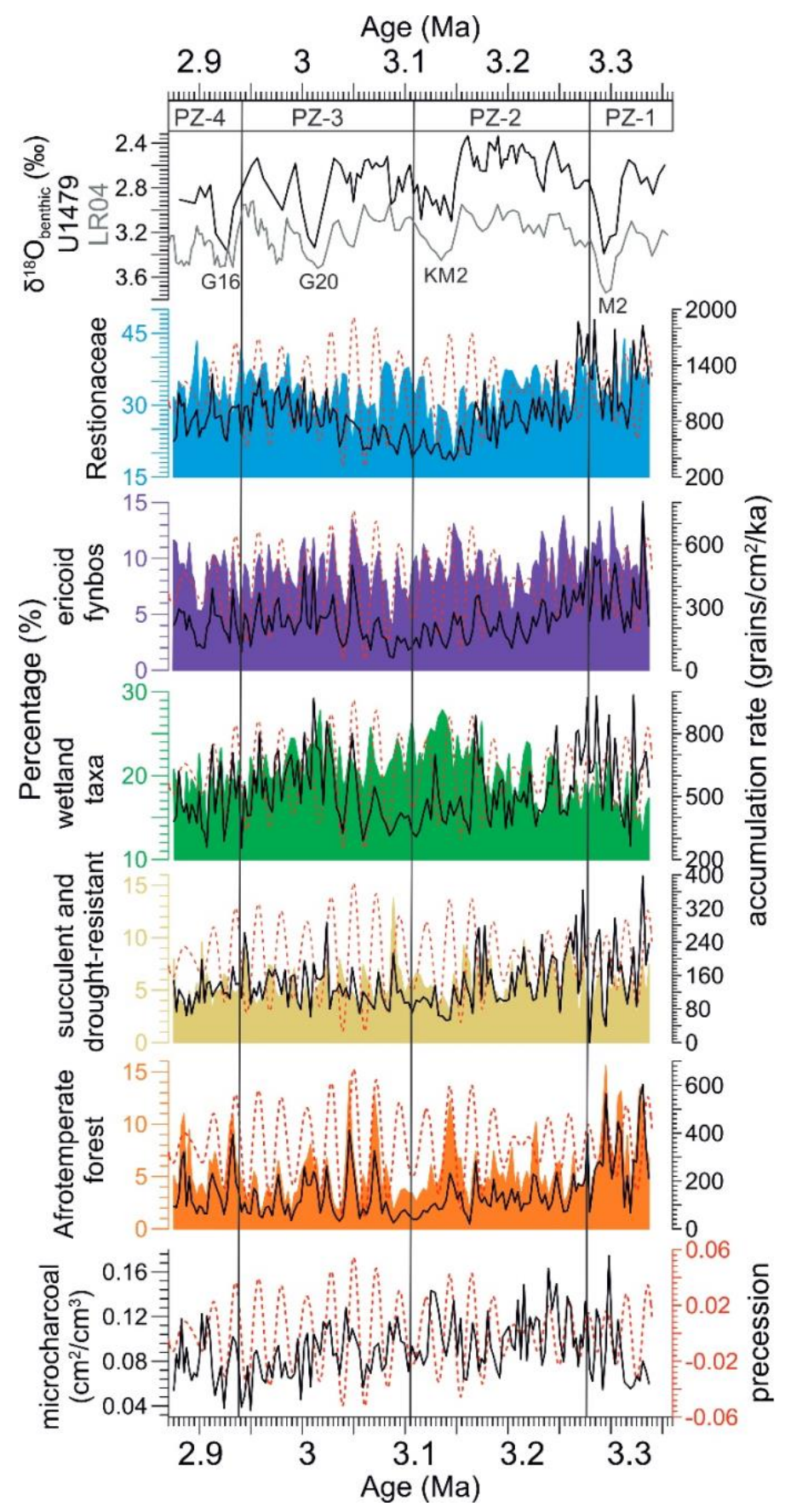

391 Figure 4. Oxygen isotopes of benthic foraminifera of IODP Site U1479 (black) compared to the global 392 stack LR04 (gray) (Lisiecki and Raymo, 2005), pollen percentages (shading) and accumulation rates 393 (lines) of four groups (Restionaceae, ericoid fynbos, wetland taxa and Afrotemperate forest) as well as 394 the microcharcoal concentrations from IODP Site U1479 overlaid with precession (dashed lines) (Laskar 395 et al., 2004).

396 The spectral analysis of the Restionaceae, ericoid fynbos, wetland taxa, succulent and drought taxa, and Afrotemperate forest pollen percentages as well as of microcharcoal concentrations show persistent significant power within the 18-24 kyr precession 
399 frequency bands (Figure 5). The same pattern is also found in the frequency analysis of pollen concentrations and accumulation rates (Supplementary Figures 1 and 2).
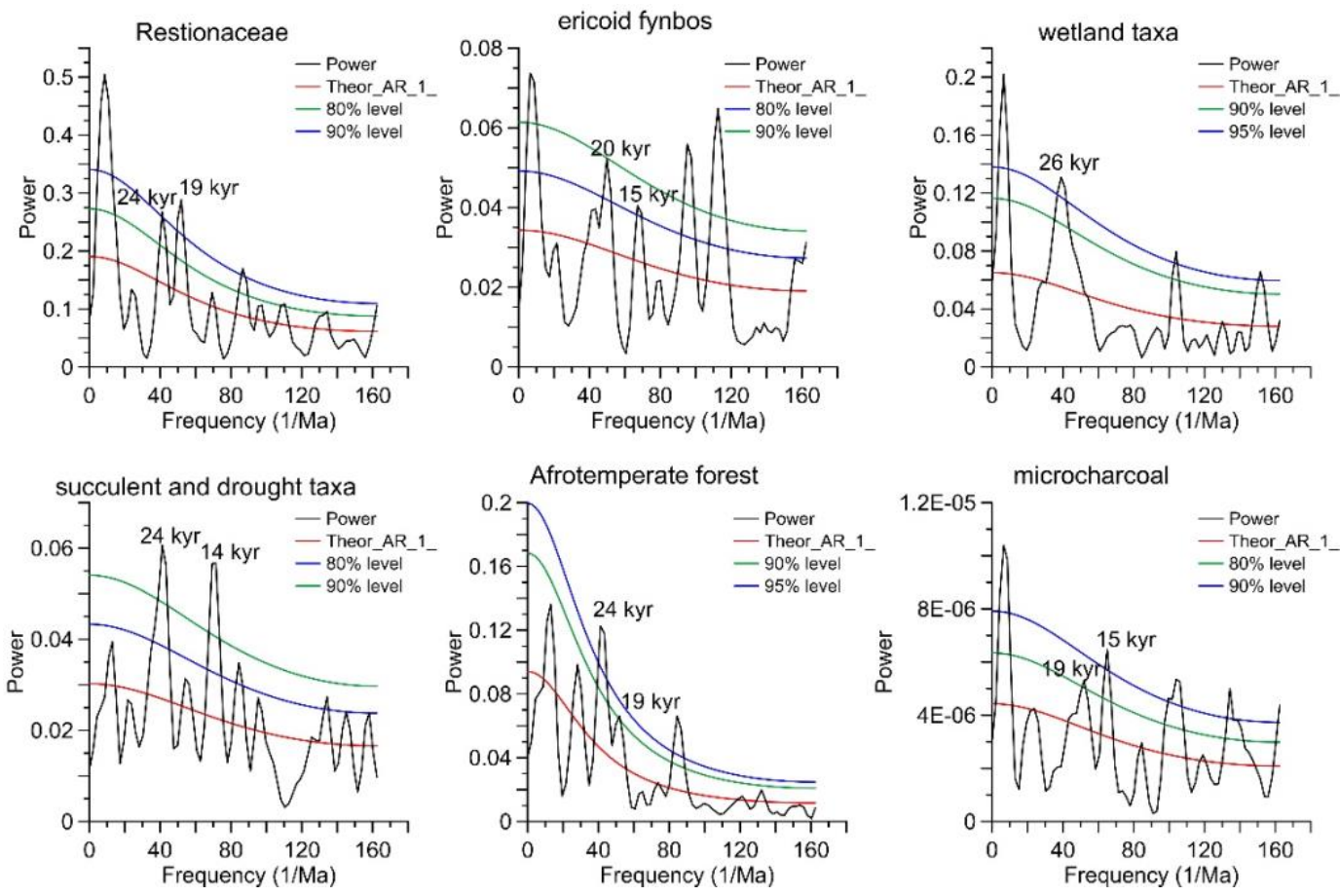

402 Figure 5. REDFIT spectral analysis (window: hanning; oversample: 2; segments: 3 ) of the percentages of different pollen groups and microcharcoal concentration from IODP Site U1479. Theor_AR_1_means

404 theoretical first-order autoregressive (AR1). False-alarm levels of $80 \%, 90 \%$ and $95 \%$ are denoted.

405 The benthic foraminifera $\delta^{18} \mathrm{O}$ record shows characteristic 'glacial-interglacial' changes 406 similar to the global LR04 benthic $\delta^{18} \mathrm{O}$ stack. The specific values are higher at Site 407 U1479. Several glacials including MIS M2, KM2, G20 and G16 correspond to the 408 minima of Restionaceae and maxima of ericoid fynbos taxa (Figure 6).

\section{Discussion}

\subsection{Pollen transport and source area}

411 Pollen and spores can be transported from the continent to the ocean either by wind 412 or by rivers. Although in the semi-arid regions of southwestern Africa, wind transport is 413 a major transport process for terrigenous material to the ocean (Prospero, 1981; Scott 414 and van Zinderen Barker, 1985), fluvial transport could also be possible. The Pliocene 
415 pollen record at ODP Site 1082 (west of Namibia, Figure 2) indicates mixed fluvial and 416 aeolian pollen transport before 2.2 Ma (Dupont, 2006). Considering that southern

417 South Africa is predominantly influenced by southern westerlies and SE trade winds

418 throughout the year, however, direct wind transport of pollen from the Cape province 419 to Site U1479 seems unlikely as the study site is situated outside the direct influence 420 of the SE trade winds (Figure 2). Pollen and spores in sediments of Site U1479 are 421 more probably transported by the rivers of the Southern Cape in to the ocean and from 422 there by the strong Agulhas Current to the study site. This is supported by the 423 continuous presence of freshwater cyst Pseudoschizaea (Rossignol, 1962) in Site 424 U1479 (Figure 3). As previous studies indicate that fine grained, wind-blown 425 terrigenous material can travel as far as the Agulhas Ridge entrained within the 426 Agulhas Current (Petschick et al., 1996), we assume that pollen and spores can also 427 be transported and deposited here. The material of Site U1479 is relatively rich in 428 pollen and spores and the floral composition of the palynological assemblage 429 dominated by the family of Restionaceae clearly points to an origin in fynbos vegetation. 430 We presume, therefore, that the Agulhas Current is instrumental in the westward 431 transport of aeolian or fluvial pollen and spores reaching the ocean along south coast 432 of South Africa. 

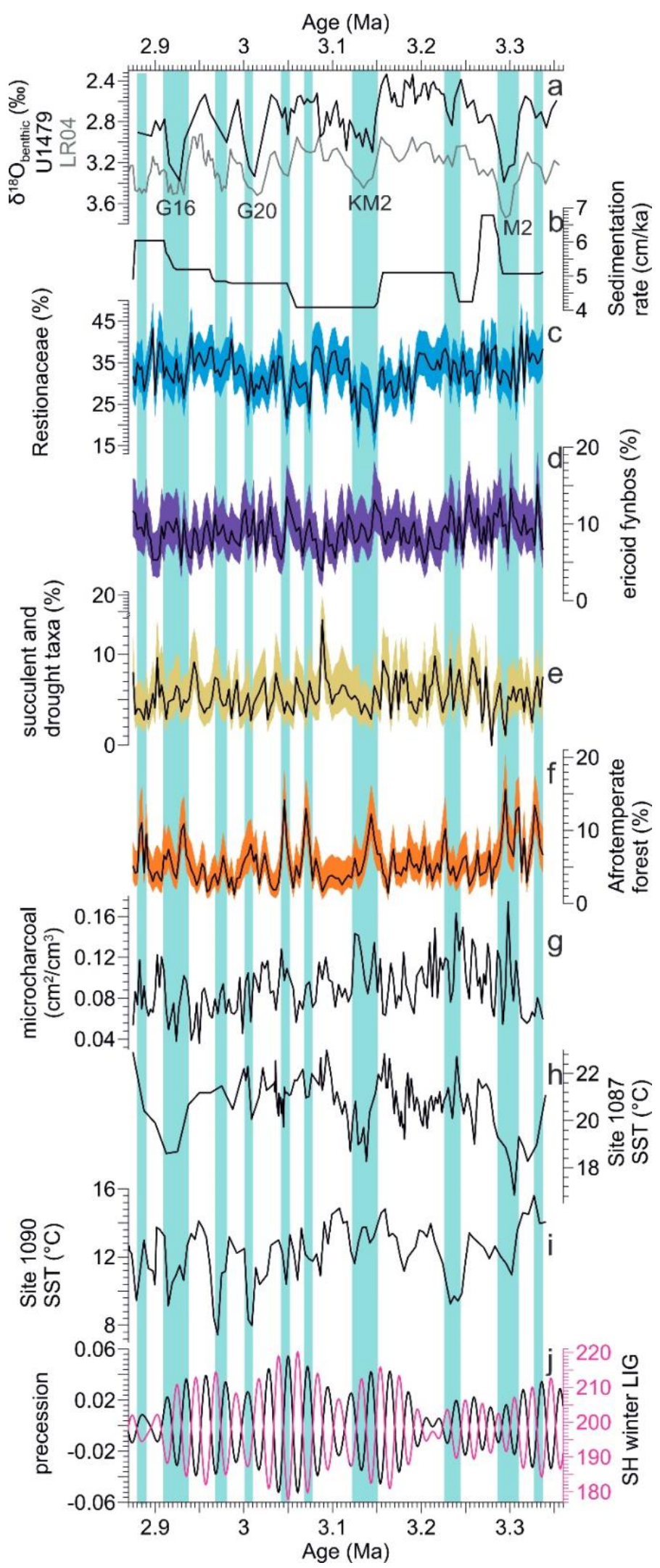

434 Figure 6. a) Oxygen isotopes of benthic foraminifera of IODP Site U1479 (black) compared to the global 435 stack LR04 (gray) (Lisiecki and Raymo, 2005); b) sedimentation rates, c-f) pollen percentages and g) microcharcoal concentrations of IODP Site U1479; h-i) alkenone-derived SSTs from ODP Sites 1087 
437 (Petrick et al., 2015, 2018) and 1090 (Martínez-García et al., 2010); j) precession (black) and southern

438 hemisphere latitudinal winter insolation gradient (LIG) (pink) (Laskar et al., 2004). Shadings of pollen

439 percentages denote $95 \%$ confidence intervals. The light blue vertical bars correspond to higher benthic 440 foraminifera $\delta^{18} \mathrm{O}$ values, lower percentages of Restionaceae, high percentages of ericoid fynbos, 441 succulent and drought taxa and Afrotemperate forest, higher values of microcharcoal concentrations in 442 IODP Site U1479 and colder SST in ODP Sites 1087 and 1090.

$443 \quad 5.2$ Vegetation and hydroclimate response on latitudinal insolation 444 gradient forcing

445 At IODP Site U1479, the late Pliocene is characterized by a long-term trend of 446 decrease prior to $3.147 \mathrm{Ma}$ and after that an increase of both the percentage values 447 and accumulation rates of Restionaceae correspond to a decrease of Ericaceae values 448 (Figures 4 and 6). The maxima of both Restionaceae and ericoid fynbos taxa before 449 3.304 Ma indicate that fynbos was the dominant vegetation group in the Cape region, 450 suggesting wetter conditions. However, the general decreasing trend in both 451 percentages and accumulation rates of Restionaceae until 3.147 Ma suggests that that 452 the climate got drier. Pollen accumulation rates depend not only on the production of 453 pollen but also on the transport efficiency. On one hand, drier conditions could result 454 in a decline of vegetation cover leading to less pollen production. On the other hand, it 455 could result in decreased river discharge which might induce less terrestrial input to 456 our core site. This might explain the inverse trend of Cyperaceae, which starts from 457 minima at the beginning of the record and reaches maxima around 3.136 Ma. 458 Cyperaceae growing in wet habitats have an ambiguous relation to wetness. The 459 climate deterioration prior to 3.147 Ma might have caused drying of shallow lakes, 460 which then became wetlands leading to an increase of sedges. The drier conditions 461 are also implied by high microcharcoal concentrations until 3.239 Ma, suggesting an 462 increase in fire under more arid and seasonal conditions and a vegetation providing 
463

enough fuel biomass (Daniau et al., 2013). After 3.239 Ma, a further decline of the

464 representation of Restionaceae was observed reaching a minimum at 3.147 Ma; at the

465 same time ericoid fynbos percentages increased to a maximum. This might suggest a shift in the composition of the fynbos. According to Mucina and Rutherford (2006), modern ericoid fynbos is the wettest type of fynbos. However, in this study, the shift to ericoid fynbos appears to be associated with the onset of drier conditions, which is supported by Valsecchi et al. (2013) who propose that ericoid fynbos is favored by drier conditions and higher fire frequencies. The pollen assemblage of the late Pleistocene inferred from the same site (IODP Site U1479) indicates a dramatic decrease in Restionaceae pollen percentages (less than 30\%) (unpublished results from Lydie Dupont) in comparison to the pollen assemblage of the middle Pliocene (this study). This suggests the existence of a no-analogue vegetation during the middle Pliocene. The high representation of succulent and drought taxa between 3.273 and $3.156 \mathrm{Ma}$ also indicates relatively dry conditions. At a first glance, this interpretation seems to be inconsistent with the minima in microcharcoal concentrations between 3.195 and 3.154 Ma indicating a decrease in fire frequencies. However, fires in southern Africa are affected by the interaction of different factors such as the peak of the dry season, fuel loads and rainfall seasonality (Daniau et al., 2013; Woillez et al., 2014). Additionally, drier conditions resulting in decreased river discharge could also be responsible for less transport of charcoal particles to the ocean. Considering the lower total pollen accumulation rates between 3.239 and $3.059 \mathrm{Ma}$, the relatively low microcharcoal concentrations are attributed to less fuel biomass and less terrestrial input into ocean. From 3.147 Ma onwards, the increase of Restionaceae pollen percentages accompanied with relatively high wetland taxa percentages, relatively low percentages of ericoid fynbos pollen and succulent and drought taxa indicate a relative increase in humidity. 

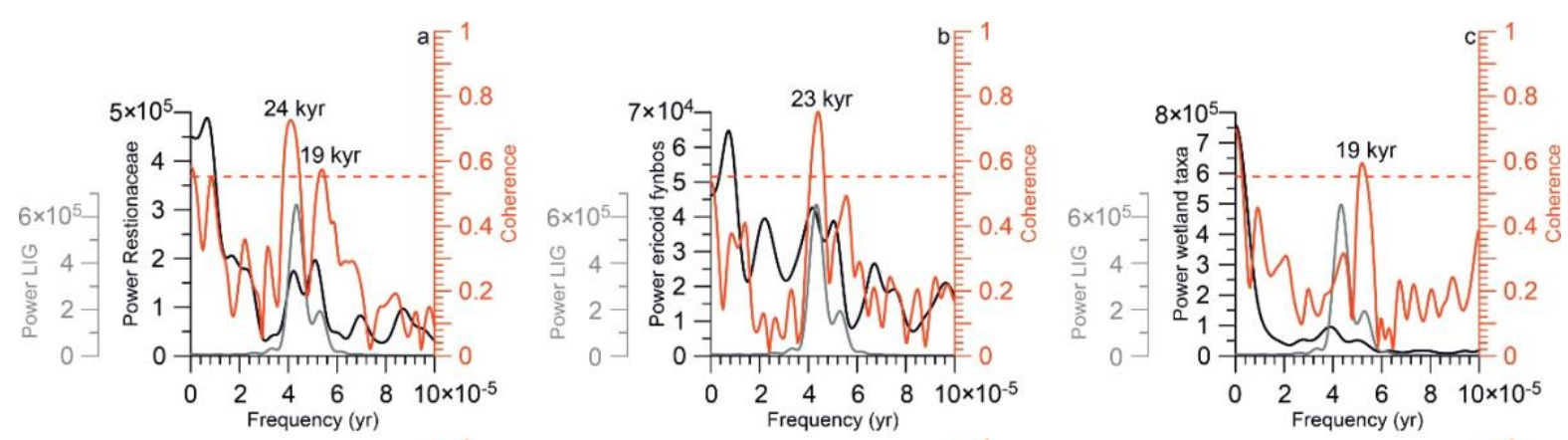

489
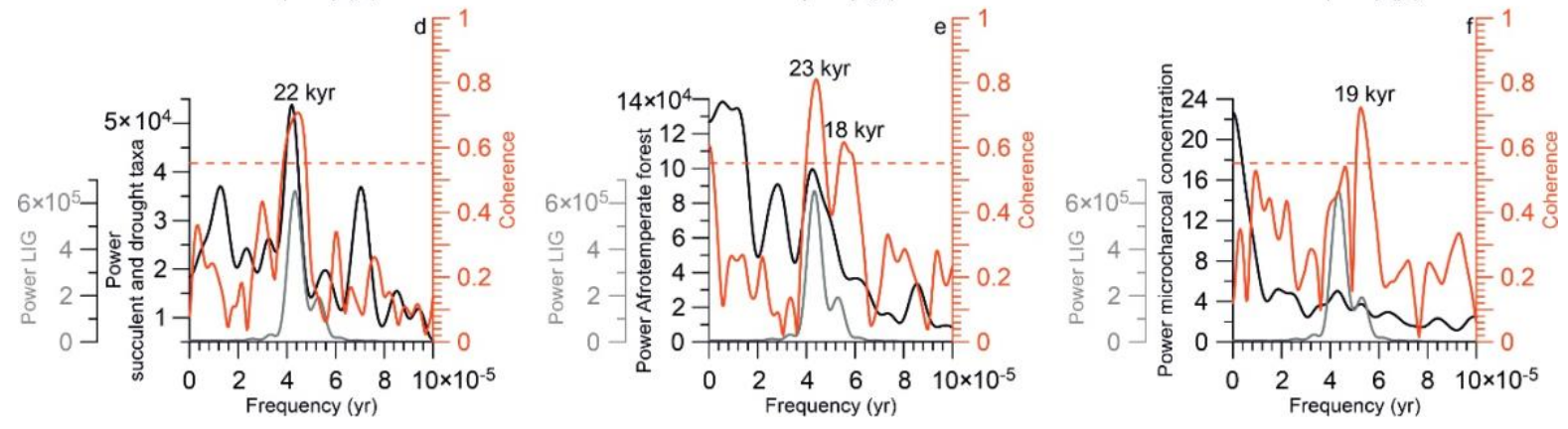

490

Figure 7. Cross spectral analysis between the percentages of different pollen groups (a, Restionaceae;

491 b, ericoid fynbos; c, wetland taxa; d, succulent and drought taxa; e, Afrotemperate forest) and 492 microcharcoal concentration (f) from IODP Site U1479 and LIG. The dash lines denote the non-zero 493 coherence limit (values higher than 0.55 are significant at the $95 \%$ confidence interval).

494 On orbital and shorter timescales, we find general relationships among the records 495 shown in Figure 6: pollen percentage minima of Restionaceae are associated with 496 maxima of ericoid fynbos, succulent drought taxa, Afrotemperate forest and 497 microcharcoal concentrations. Spectral analysis of the percentage values of 498 Restionaceae, ericoid fynbos, succulent and drought taxa, and Afrotemperate forest 499 as well as microcharcoal concentrations indicates significant periods of $18-24 \mathrm{kyr}$, 500 suggesting a strong effect of precession (Figure 5). The results of cross spectral 501 analysis support our interpretation indicating significant correlation between pollen 502 groups and LIG at precession cycles (18-24 kyr) (Figure 7). Minima in Restionaceae 503 occur in phase with maxima in precession and minima in LIG between 60 and $30^{\circ} \mathrm{S}$ of 504 the southern hemisphere winter (21 June) (Supplementary Figure 3). Leads or lags 505 occur in ericoid fynbos (lag of $9500 \mathrm{yr}$ ), wetland taxa (lag of $9500 \mathrm{yr}$ ), Succulent and 
506 drought taxa (slight lead of $1400 \mathrm{yr}$ ), Afrotemperate forest (lead of $9200 \mathrm{yr}$ at $23 \mathrm{kyr}$ cycle and 6100 at $18 \mathrm{kyr}$ cycle) and microcharcoal concentration (lag of $8300 \mathrm{yr}$ ).

508 The dominance of precession cycles in the pollen signal might be the effect of the 509 latitudinal temperature gradient during the southern hemisphere winter approximated 510 by the LIG, which is important in the forcing of the climate in the winter rainfall regions 511 of the mid-latitudes (Davis and Brewer, 2009). A Holocene model climate study shows 512 that a weaker latitudinal temperature gradient leads to weaker mid-latitude westerly 513 flow, weaker cyclones and reduced mid-latitude precipitation (Routson et al., 2019). A 514 reduced equator-to-pole winter temperature gradient was also observed to be related 515 to a reduced equator-to-pole insolation gradient and reduced storm track activity over 516 the Mediterranean Sea using a high-resolution coupled climate mode (Bosmans et al., 517 2015). A weak southern hemisphere winter gradient would weaken the southern westerlies and reduce winter precipitation in both the WRZ and the YRZ (Figure 8). Restionaceae, which have a strong winter-rainfall affiliation (Cowling et al., 1997), decline due to the relatively dry conditions and reduced rainfall seasonality. Whereas, 521 in comparison to Restionaceae, ericoid fynbos is more favored by drier conditions. 522 Thus, the reduced winter precipitation and less Restionaceae will cause a relative increase of ericoid fynbos. Based on pollen records, we could only refer that the relative abundance of ericoid fynbos is higher which might be resulted from their areal extent. The drier conditions also likely caused higher fire frequencies. The high-resolution 526 marine sediment core MD96-2098 off Namibia during the past 170,000 years in 527 southern Africa indicates high fire activity during precession maxima (Daniau et al., 528 2013), which is well supported by the microcharcoal-based reconstructions of past fire activity during MIS4 in southern Africa (Woillez et al., 2014). In the YRZ, the high values of Afrotemperate forest suggest more summer rainfall (Dupont et al., 2011; Quick et 531 al., 2018). Conversely a strong gradient would strengthen the westerlies and 

westerlies would result in humid conditions and intensified rainfall seasonality, leading

534 to high values of Restionaceae and lower values of ericoid fynbos as well as low fire 535 frequencies. A pollen and microcharcoal record from the coastal lake Eilandvlei shows 536 that the general long-term trend of increasing Afrotemperate forest with decreasing 537 fynbos was probably associated with reduced rainfall seasonality and more influences 538 of summer rainfall in maintaining higher moisture availability in the region (Quick et al., 2018). Thus, in the $Y R Z$, the intensified rainfall seasonality and more winter rainfall

540 would hamper the growth of Afrotemperate forest. The pollen record suggests a 541 response of the vegetation to trends in the average winter precipitation by variations in 542 the proportion of Ericaceae in the fynbos. Shifts between the amounts of winter and 543 summer rainfall in the YRZ influenced the development of Afrotemperate forest (Figure 544 6). In conclusion, we infer that the vegetation variation at the Cape region reflects 545 moisture variability during the mPWP which is related to the LIG in response to 546 precession forcing.
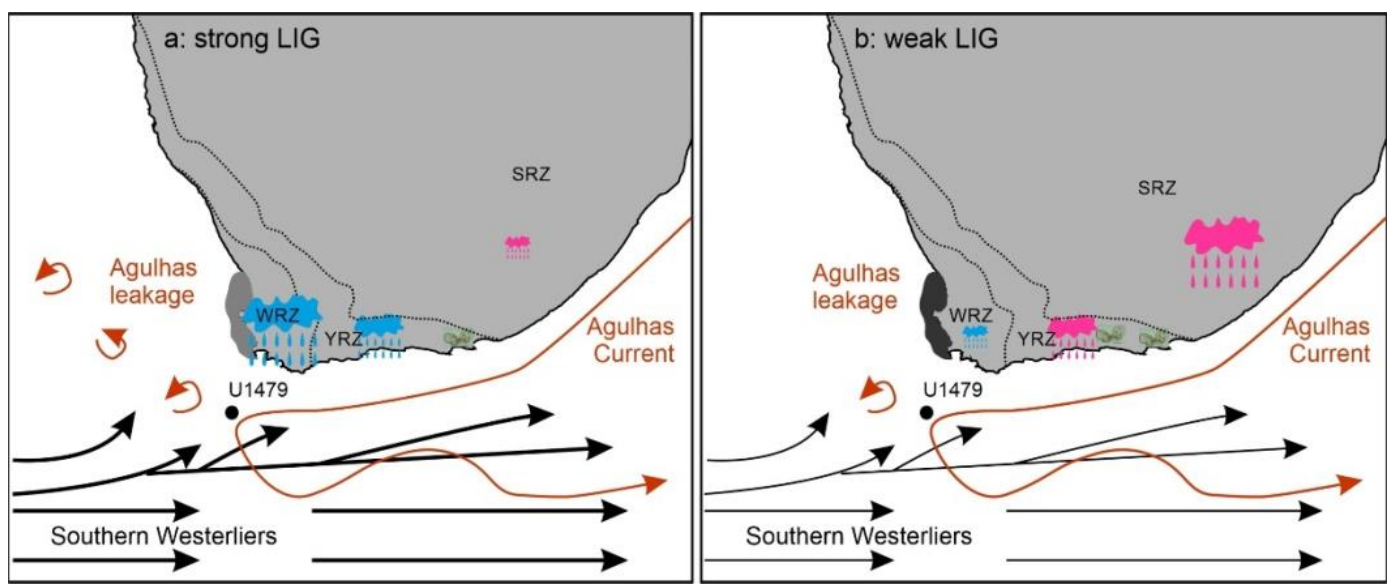

548 Figure 8. Conceptional model explaining the environmental variability for two different cases during the 549 mPWP in southern Africa. a) strong latitudinal insolation gradient (LIG) inducing strong southern 550 westerlies and warmer SST resulting from Antarctic sea ice retreat, stronger Agulhas leakage and/or 551 weakened upwelling. b) weak LIG inducing weak southern westerlies and cooler SST resulting from 552 Antarctic sea ice expansion, reduced Agulhas leakage and/or strengthened upwelling. 
554 sea surface temperatures (SST)

555 Even within the mPWP there are several glacials. In particular, the pronounced glacial 556 stage just before the onset of the mPWP known as "M2 glaciation" at 3.295 Ma in the 557 global stack LR04 $\delta^{18} \mathrm{O}_{\text {benthics }}$ record (Lisiecki and Raymo, 2005) has been interpreted 558 as an early major global cooling event prior to the onset of the northern hemisphere 559 glaciations at ca. 2.6 Ma (De Schepper et al., 2009; Prell, 1984). A short interval with 560 lower values of Restionaceae and high values of ericoid fynbos as well as 561 Afrotemperate forest between 3.331 and 3.160 Ma was observed, which is broadly 562 coincident with this glacial MIS M2 (Figure 6). This is supported by the X-ray 563 Fluorescence (XRF) data from IODP Site U1478 off Limpopo which suggest increased 564 runoff during the MIS M2 in the Mozambique Channel probably related to increased 565 rainfall in the SRZ (Koutsodendris et al., 2020). However, the most pronounced period 566 in our pollen record occurs between 3.147 and 3.129 Ma when Restionaceae 567 percentages reach minima together with high values of ericoid fynbos (Figure 6). The 568 period corresponds to another glacial, MIS KM2, which is also considered to be one of

569 the pronounced glacials during the Pliocene (De Schepper et al., 2009). This is 570 supported by the high pollen percentage values of Ericaceae, which are often used as 571 an indicator of colder climate (Gasse and Van Campo, 1998; Scott, 1999). Apart from 572 these two glacials, there are several other glacials characterized by low percentage values of Restionaceae, high percentage values of ericoid fynbos and Afrotemperate

574 forest in our pollen record. The glacials correspond well with cold SST recorded at 575 ODP Sites 1087 and 1090 (Figure 6) (Martínez-García et al., 2010; Petrick et al., 2015, 576 2018). The TEX 86 data from IODP Site U1478 off Limpopo also show a long-term SST 577 drop centered at ca. 3.2-3.1 Ma (Taylor et al., in review). We infer that SST influenced 
578 hydroclimate variability and in turn vegetation during the MPWP. The colder SST would 579 reduce temperatures as well as winter rainfall in the WRZ and YRZ, which would lead 580 to a decline in Restionaceae and an increase in ericoid fynbos. The reduced 581 temperature and precipitation in the WRZ of southern Africa would thus enhance the 582 effect of weak winter LIG.

583 Numerical modelling supports our interpretation. Rreconstructed SST were simulated 584 and used to force a numerical climate model (Kamae et al., 2011). The results reveal 585 that wetter surface conditions in subtropical Africa during the mPWP are related to the 586 reduction of the meridional and zonal gradients of tropical SST rather than to orography, 587 land and/or sea ice. In this region, however, it is hard to distinguish between the 588 different factors resulting in variations of SST, which is affected by the interactions of 589 Agulhas leakage, Benguela Current as well as the advection of cold sub-Antarctic 590 water (Rosell-Melé et al., 2014).

591 Firstly, a decline in SST might be attributed to the global cooling triggered by Antarctic 592 ice sheet expansion. Proxy records and model studies generally infer a more northward 593 position of the southern westerlies during cooler climates/glacial periods (Bard and 594 Rickaby, 2009; Lamy et al., 2004; Williams and Bryan, 2006). A 800,000 year record 595 of SST and ocean productivity from marine sediment core MD96-2077 situated under 596 the Agulhas Current of the subtropical gyre of the Indian Ocean suggests a northward 597 shift of the southern westerlies by up to $7^{\circ}$ of latitude during cooler stages (Bard and 598 Rickaby, 2009). This supports the model results of a $7^{\circ}$ equatorward shift of the 599 subtropical fronts resulting from a global cooling of $3^{\circ} \mathrm{C}$ (Williams and Bryan, 2006). 600 The inference of weakened southern westerlies induced by the weak LIG during 601 glacials based on our pollen and microcharcoal records implies that there might be 602 some decoupling between the strength and the latitudinal position of the southern 
603 westerlies. During glacials, northerly positioned southern westerlies might still show 604 fluctuations in strength.

605 Secondly, a decline in SST might be attributed to less Agulhas leakage. Previous 606 studies have shown that the northward shift of the southern westerlies during glacials 607 nearly shuts off the Agulhas leakage (Bard and Rickaby, 2009; Peeters et al., 2004). 608 The initial results of geochemical provenance studies on clays at our Site U1479 609 indicate reduced Agulhas leakage during the last glacial cycle and enhanced Agulhas 610 leakage during warmer periods (Franzese et al., 2018). The reconstructions of ice 611 sheet, SST and sea ice from an Antarctic sediment core showed that the intensification 612 of Antarctic cooling resulted in the expansion of southern westerlies and the northward 613 migration of ocean fronts in the Southern Ocean, which likely restricted the warm 614 Agulhas leakage (McKay et al., 2012). In this case, the low SST might be associated with less Agulhas leakage influenced by the northward shift and weakened southern westerlies during weak LIG. This is supported by the relatively cool SST and very low

617 abundances of Agulhas leakage indicator foraminifera (e.g., Globigerina falconensis 618 and Globorotalia menardii) at ODP Site 1087 suggesting an absence or weak influence 619 of Agulhas leakage during the mPWP (Petrick et al., 2015). The high representation of 620 Podocarpaceae during glacials in combination with restricted Agulhas leakage refutes 621 the idea of abundant Podocarpaceae pollen transport by the Agulhas Current from 622 southeastern South Africa. More likely, therefore, is that abundant pollen of 623 Podocarpaceae originated from Afrotemperate forest in the YRZ. Although it is widely 624 accepted that the southward shift of the southern westerlies would enable more 625 Agulhas leakage (Biastoch et al., 2009), the modeling study of Durgadoo et al. (2013) 626 emphasized that increased Agulhas leakage corresponds with increased intensity of 627 the southern westerlies, which would concur with our "strong LIG" case shown in 628 Figure 8. 
629 Thirdly, a decline in SST might mark the switch from a warm to a cold mode of SE 630 trade wind-induced upwelling along the southwest African coast. Grain size data and 631 alkenone-based SST from sediment cores MD96-2086/87 located off Lüderitz (off

632 Namibia, SW Africa) indicate that the past long-term SST variations are primarily 633 induced by strengthened SE trade winds through intensified coastal upwelling 634 (Pichevin et al., 2005). The latest model results indicate intensification of upwelling of 635 colder waters in the Benguela Upwelling region during the Pleistocene resulting in 636 strongly lowered SST compared to the Pliocene, which is not simulated by global 637 models with a relatively coarse geographical resolution (Jung et al., 2014; Haywood et 638 al., 2020, accepted; McClymont et al., 2020). Although the upwelling was still weak 639 during the middle Pliocene, several studies have shown evidence of an upwelling 640 maximum in the southern Benguela system until ca. 2.8 Ma, which later progressed 641 northwards to its modern position offshore Lüderitz (Diekmann et al., 2003; Petrick et 642 al., 2015, 2018; Rommerskirchen et al., 2011). Fossil mollusc records from the west 643 coast of southern Africa indicate the existence of cold upwelling offshore south of $32^{\circ} \mathrm{S}$ 644 in the early Pleistocene (Tankard and Rogers, 1978). Alkenone-derived SST records 645 from the Agulhas Basin to the northern Benguela system indicate different patterns of 646 SST since 5 Ma (Etourneau et al., 2009; Martínez-García et al., 2010; Petrick et al., 647 2015, 2018; Rommerskirchen et al., 2011; Rosell-Melé et al., 2014), suggesting 648 upwelling was controlled by different processes in the southern and northern Benguela 649 system. This is for instance supported by the absence of cold SST in the northern 650 Benguela system (ODP Sites1084, 1082 and 1081) during the glacials MIS M2 and 651 KM2 (Petrick et al., 2015). Multiproxy studies suggest more extensive upwelling in the 652 southern Benguela system during the mPWP (Petrick et al., 2015). The global cooling 653 with increased Antarctic glaciations promoting intermediate and bottom water 654 formation combined with intensified SE trade winds (intensified Hadley circulation) and 
655 uplift of East Africa would have caused intensified upwelling offshore of southern Africa

656 (Etourneau et al., 2009; Jung et al., 2014; Marlow et al., 2000; Rommerskirchen et al., 657 2011; Rosell-Melé et al., 2014). In our "weak LIG" case, the weakened southern 658 westerlies combined with strong SE trade winds would cause intensified upwelling, 659 resulting in cold water conditions over our core site and less rainfall in the WRZ. 660 Whereas in the "strong LIG" case, the strong southern westerlies and weak SE trade 661 winds would cause weakened upwelling (Figure 8).

\section{Conclusions}

663 The development of vegetation and climate in southwestern South Africa during the 664 mid-Piacenzian have been documented in detail by pollen, microcharcoal and benthic 665 foraminifera oxygen isotope records from marine sediment cores of IODP Site U1479 666 retrieved from the Cape Basin offshore of South Africa covering the period from 3.337 to $2.875 \mathrm{Ma}$.

668 Pollen assemblages throughout the record are characterized by the family of 669 Restionaceae indicating a clear pollen source from fynbos vegetation during the $670 \mathrm{mPWP}$. Variations in the representation of Restionaceae, ericoid fynbos and 671 Afrotemperate forest show dominant precession cycles indicating influence by the

672 latitudinal insolation gradient (LIG) in response to precession forcing. The weak/strong 673 southern hemisphere winter gradient would weaken/strengthen the southern 674 westerlies and winter precipitation in the $W R Z$ and $Y R Z$ as well as influence the relative 675 amounts between winter and summer rainfall in the YRZ.

676 The glacial events reflected by the benthic foraminifera oxygen isotope record 677 correspond well with cooler SE Atlantic sea surface temperatures (SST) off South 678 Africa and are consistent with the vegetation and hydroclimate variability deduced from 679 our pollen and microcharcoal records. The cooler SST inducing less rainfall in the 
680 winter rainfall zone, were likely driven by interactions of both atmospheric and 681 oceanographic processes including Antarctic ice sheet expansion, less contribution of 682 the Agulhas leakage and/or intensified southern Benguela upwelling.

683 On the basis of our study and comparisons with published records offshore of 684 southwestern Africa, we propose that LIG forcing (precession) and SST forcing were 685 the main drivers of hydroclimate in southwestern South Africa during the mPWP. 686 During "weak LIG", the weakened southern westerlies combined with cold SST result 687 in less rainfall in the WRZ, while during "strong LIG", the strong southern westerlies 688 together with warm SST would bring more rainfall in the WRZ.

\section{Acknowledgments}

690 This study was financially supported by the International Ocean Discovery Program, 691 IODP (SPP527) of the Deutsche Forschungsgemeinschaft (DFG), grant Nr. DU221/7.

692 Thibaut Caley is supported by CNRS-INSU. Funding from IODP France and LEFE 693 IMAGO CNRS INSU project SeaSalt are acknowledged. We thank the Captain, officers, 694 crew and especially all scientists sailing on IODP expedition 361. Thanks to Jutta 695 Scheffing for assistance with the pollen sample preparations in the lab. We would like 696 to thank the two reviewers for their helpful and constructive comments that have helped 697 to improve the manuscript.

\section{References}

699 Bard, E., Rickaby, R.E., 2009. Migration of the subtropical front as a modulator of glacial climate. Nature 460, 380-383, https://doi.org/10.1038/nature08189.

701 Bergh, N.G., Verboom, G., Rouget, M., Cowling, R.M., 2014. Vegetation types of the greater cape floristic region, in: Allsopp, N., Colville, J.F., Verboom, G.A. (Eds.), Fynbos: Ecology, evolution, and conservation of a megadiverse region. Oxford University Press. 
Biastoch, A., Böning, C.W., Schwarzkopf, F.U., Lutjeharms, J., 2009. Increase in Agulhas leakage due to poleward shift of Southern Hemisphere westerlies. Nature 462, 495498, https://doi.org/10.1038/nature08519.

Bond, W., 1996. Fire, in: Cowling, R., Richardson, D., Pierce, S. (Eds.), The vegetation of southern Africa. Cambridge University Press: Cambridge, pp. 421-446.

Bonnefille, R., Riollet, G., 1980. Pollen des savanes d'Afrique orientale. Éditions du Centre national de la recherche scientifique, Paris.

Bosmans, J., Drijfhout, S., Tuenter, E., Hilgen, F., Lourens, L.J., Rohling, E., 2015. Precession and obliquity forcing of the freshwater budget over the Mediterranean. Quaternary Science Reviews 123, 16-30, http://dx.doi.org/10.1016/j.quascirev.2015.06.008.

Burls, N.J., Fedorov, A.V., 2017. Wetter subtropics in a warmer world: Contrasting past and future hydrological cycles. Proceedings of the National Academy of Sciences 114, 12888-12893, https://doi.org/10.1073/pnas.1703421114.

Carr, A.S., Boom, A., Grimes, H.L., Chase, B.M., Meadows, M.E., Harris, A., 2014. Leaf wax n-alkane distributions in arid zone South African flora: Environmental controls, chemotaxonomy and palaeoecological implications. Organic Geochemistry 67, 72-84, https://doi.org/10.1016/j.orggeochem.2013.12.004.

Chase, B.M., Meadows, M.E., 2007. Late Quaternary dynamics of southern Africa's winter rainfall zone. Earth-Science Reviews 84, 103-138, https://doi.org/10.1016/j.earscirev.2007.06.002.

Clark, R.L., 1982. Point count estimation of charcoal in pollen preparations and thin sections of sediments. Pollen et spores 24, 23-35.

Cowling, R.M., Richardson, D.M., Pierce, S.M., 1997. Vegetation of southern Africa. Cambridge University Press, Cambridge.

Crowley, T.J., 1996. Pliocene climates: the nature of the problem. Marine Micropaleontology 27, 3-12, https://doi.org/10.1016/0377-8398(95)00049-6.

Daniau, A.-L., Sánchez Goñi, M.F., Martinez, P., Urrego, D.H., Bout-Roumazeilles, V., Desprat, S., Marlon, J.R., 2013. Orbital-scale climate forcing of grassland burning in southern 
Africa. Proceedings of the National Academy of Sciences 110, 5069-5073, https://doi.org/10.1073/pnas.1214292110.

Davis, B.A.S., Brewer, S., 2009. Orbital forcing and role of the latitudinal insolation/temperature gradient. Climate Dynamics 32, 143-165, https://doi.org/10.1007/s00382-008-0480-9.

De Schepper, S., Head, M.J., Groeneveld, J., 2009. North Atlantic Current variability through marine isotope stage M2 (circa 3.3 Ma) during the mid-Pliocene. Paleoceanography 24, https://doi.org/10.1029/2008pa001725.

Diekmann, B., Fälker, M., Kuhn, G., 2003. Environmental history of the south-eastern South Atlantic since the Middle Miocene: evidence from the sedimentological records of ODP Sites 1088 and 1092. Sedimentology 50, 511-529, https://doi.org/10.1046/j.13653091.2003.00562.x.

Dowsett, H.J., Cronin, T.M., Poore, R.Z., Thompson, R.S., Whatley, R.C., Wood, A.M., 1992. Micropaleontological Evidence for Increased Meridional Heat Transport in the North

Dolan, A.M., Haywood, A.M., Hill, D.J., Dowsett, H.J., Hunter, S.J., Lunt, D.J., Pickering, S.J., 2011. Sensitivity of Pliocene ice sheets to orbital forcing. Palaeogeography, Palaeoclimatology, Palaeoecology 309 , 98-110, https://doi.org/10.1016/j.palaeo.2011.03.030.

Atlantic Ocean During the Pliocene. Science 258, 1133-1135. https://doi.org/10.1126/science.258.5085.1133.

Dupont, L.M., 2006. Late Pliocene vegetation and climate in Namibia (southern Africa) derived from palynology of ODP Site 1082. Geochemistry, Geophysics, Geosystems 7, https://doi.org/10.1029/2005gc001208.

Dupont, L.M., Linder, H.P., Rommerskirchen, F., Schefuß, E., 2011. Climate-driven rampant speciation of the Cape flora. Journal of Biogeography 38, 1059-1068, https://doi.org/10.1111/j.1365-2699.2011.02476.x.

758 Durgadoo, J.V., Loveday, B.R., Reason, C.J., Penven, P., Biastoch, A., 2013. Agulhas leakage predominantly responds to the Southern Hemisphere westerlies. Journal of Physical 
Eckardt, F., Kuring, N., 2005. SeaWiFS identifies dust sources in the Namib Desert. International Journal of Remote Sensing 26, 4159-4167, https://doi.org/10.1080/01431160500113112.

764 Engelbrecht, C.J., Landman, W.A., Engelbrecht, F.A., Malherbe, J., 2015. A synoptic 765 decomposition of rainfall over the Cape south coast of South Africa. Climate Dynamics 44, 2589-2607, https://doi.org/10.1007/s00382-014-2230-5.

Etourneau, J., Martinez, P., Blanz, T., Schneider, R., 2009. Pliocene-Pleistocene variability of 768 upwelling activity, productivity, and nutrient cycling in the Benguela region. Geology 37, 871-874, https://doi.org/10.1130/g25733a.1.

Franzese, A.M., Hemming, S.R., Pearson, B., Kafando, O., Sinadinse, A., 2018. Assessing Agulhas Leakage using Terrigenous Sediment Provenance at IODP Site U1479: Initial Results, AGU Fall Meeting Abstracts.

Goldblatt, P., Manning, J.C., 2002. Plant diversity of the Cape region of southern Africa. Annals of the Missouri Botanical Garden, 281-302, https://doi.org/10.2307/3298566.

Grimm, E., 2015. Tilia and TGView 19 version 2.0. 41. software. Springfield, USA: Illinois State Museum, Research and Collection Center.

Hall, I., Hemming, S., LeVay, L., Barker, S., Berke, M., Brentegani, L., Caley, T., Cartagena-

Hammer, Ø., Harper, D.A., Ryan, P.D., 2001. PAST: Paleontological statistics software package for education and data analysis. Palaeontologia electronica 4, 9.

Haywood, A.M., Dowsett, H.J., Valdes, P.J., Lunt, D.J., Francis, J.E., Sellwood, B.W., 2009. Sierra, A., Charles, C., Coenen, J., 2017. Site U1479, Proceedings of the International Ocean Discovery Program, 361. International Ocean Discovery Program. Introduction. Pliocene climate, processes and problems. Philosophical Transactions of the Royal Society A: Mathematical, Physical and Engineering Sciences 367, 3-17, https://doi.org/10.1098/rsta.2008.0205. 
Haywood, A.M., Hill, D.J., Dolan, A.M., Otto-Bliesner, B.L., Bragg, F., Chan, W.L., Chandler, M.A., Contoux, C., Dowsett, H.J., Jost, A., Kamae, Y., Lohmann, G., Lunt, D.J., AbeOuchi, A., Pickering, S.J., Ramstein, G., Rosenbloom, N.A., Salzmann, U., Sohl, L., Stepanek, C., Ueda, H., Yan, Q., Zhang, Z., 2013. Large-scale features of Pliocene climate: results from the Pliocene Model Intercomparison Project. Climate of the Past 9, 191-209, https://doi.org/10.5194/cp-9-191-2013.

Haywood, A.M., Tindall, J.C., Dowsett, H.J., Dolan, A.M., Foley, K.M., Hunter, S.J., Hill, D.J., Chan, W.L., Abe-Ouchi, A., Stepanek, C., Lohmann, G., Chandan, D., Peltier, W.R., Tan, N., Contoux, C., Ramstein, G., Li, X., Zhang, Z., Guo, C., Nisancioglu, K.H., Zhang, Q., Li, Q., Kamae, Y., Chandler, M.A., Sohl, L.E., Otto-Bliesner, B.L., Feng, R., Brady, E.C., von der Heydt, A.S., Baatsen, M.L.J., Lunt, D.J., 2020. A return to large-scale features of Pliocene climate: the Pliocene Model Intercomparison Project Phase 2. Climate of the Past Discuss. 2020, 1-40, https://doi.org/10.5194/cp-2019-145.

Haywood, A.M., Valdes, P.J., 2004. Modelling Pliocene warmth: contribution of atmosphere, oceans and cryosphere. Earth and Planetary Science Letters 218, 363-377, https://doi.org/10.1016/S0012-821X(03)00685-X.

Hijmans, R., Cameron, S., Parra, J., Jones, P., Jarvis, A., Richardson, K., 2005. WorldClim, version 1.3, University of California, Berkeley.

Hunter, S.J., Haywood, A.M., Dolan, A.M., Tindall, J.C., 2019. The HadCM3 contribution to PlioMIP phase 2. Climate of the Past 15, 1691-1713, https://doi.org/10.5194/cp-151691-2019.

Jung, G., Prange, M., Schulz, M., 2014. Uplift of Africa as a potential cause for Neogene intensification of the Benguela upwelling system. Nature Geoscience 7, 741-747, https://doi.org/10.1038/ngeo2249.

Kamae, Y., Ueda, H., Kitoh, A., 2011. Hadley and Walker circulations in the mid-Pliocene warm period simulated by an atmospheric general circulation model. Journal of the Meteorological Society of Japan. Ser. II 89, 475-493, https://doi.org/10.2151/jmsj.2011505. 
817 Koutsodendris, A., Nakajima, K., Kaboth-Bahr, S., Berke, M.A., Franzese, A.M., Hall, I.R., Hemming, S.R., Just, J., LeVay, L.J., Pross, J., Robinson, R., and IODP Expedition 361 scientists, 2020: A Plio-Pleistocene (c. 0 - 4 Ma) cyclostratigraphy for IODP Site U1478 (Mozambique Channel, SW Indian Ocean): Exploring an offshore record of paleoclimate and ecosystem variability in SE Africa. Newsletters on Stratigraphy, https://doi.org/10.1127/nos/2020/0608.

Lamy, F., Kaiser, J., Ninnemann, U., Hebbeln, D., Arz, H.W., Stoner, J., 2004. Antarctic timing of surface water changes off Chile and Patagonian ice sheet response. Science 304, 1959-1962, https://doi.org/10.1126/science.1097863.

Laskar, J., Robutel, P., Joutel, F., Gastineau, M., Correia, A.C.M., Levrard, B., 2004. A longterm numerical solution for the insolation quantities of the Earth. A\&A 428, 261-285, https://doi.org/10.1051/0004-6361:20041335.

Lau, W.K.M., Wu, H.T., Kim, K.M., 2013. A canonical response of precipitation characteristics to global warming from CMIP5 models. Geophysical Research Letters 40, 3163-3169,

Linder, H.P., 2003. The radiation of the Cape flora, southern Africa. Biological Reviews 78, https://doi.org/10.1002/grl.50420.

Levin, N.E., 2015. Environment and climate of early human evolution. Annual Review of Earth and Planetary Sciences 43, 405-429, https://doi.org/10.1146/annurev-earth-060614-

Lisiecki, L.E., Raymo, M.E., 2005. A Pliocene-Pleistocene stack of 57 globally distributed benthic $\delta 180$ records. Paleoceanography 20, https://doi.org/10.1029/2004pa001071.

Lunt, D.J., Haywood, A.M., Schmidt, G.A., Salzmann, U., Valdes, P.J., Dowsett, H.J., Loptson, C.A., 2012. On the causes of mid-Pliocene warmth and polar amplification. Earth and Planetary Science Letters 321, 128-138, https://doi.org/10.1016/j.epsl.2011.12.042.

Maher, L.J., 1972. Nomograms for computing 0.95 confidence limits of pollen data. Review of Palaeobotany and Palynology 13, 85-93, http://dx.doi.org/10.1016/00346667(72)90038-3. 
845 Marchitto, T., Curry, W., Lynch-Stieglitz, J., Bryan, S., Cobb, K., Lund, D., 2014. Improved

846

847

848

849

850

851

852

853

854

855

856

857

858

859

860

861

862

863

864

865

866

867

868

869

870

871 oxygen isotope temperature calibrations for cosmopolitan benthic foraminifera. $\begin{array}{llll}\text { Geochimica } & \text { et } & \text { Cosmochimica } & \text { 1-11, }\end{array}$ https://doi.org/10.1016/j.gca.2013.12.034.

Martin, H., 2006. Cenozoic climatic change and the development of the arid vegetation in Australia. Journal of Arid Environments 66, 533-563, https://doi.org/10.1016/j.jaridenv.2006.01.009.

Martínez-García, A., Rosell-Melé, A., McClymont, E.L., Gersonde, R., Haug, G.H., 2010. Subpolar Link to the Emergence of the Modern Equatorial Pacific Cold Tongue. Science 328, 1550-1553, https://doi.org/10.1126/science.1184480.

McClymont, E.L., Ford, H.L., Ho, S.L., Tindall, J.C., Haywood, A.M., Alonso-Garcia, M., Bailey, I., Berke, M.A., Littler, K., Patterson, M.O., Petrick, B., Peterse, F., Ravelo, A.C., Risebrobakken, B., De Schepper, S., Swann, G.E.A., Thirumalai, K., Tierney, J.E., van der Weijst, C., White, S., Abe-Ouchi, A., Baatsen, M.L.J., Brady, E.C., Chan, W.L., Chandan, D., Feng, R., Guo, C., von der Heydt, A.S., Hunter, S., Li, X., Lohmann, G., Nisancioglu, K.H., Otto-Bliesner, B.L., Peltier, W.R., Stepanek, C., Zhang, Z., 2020. Lessons from a high-CO2 world: an ocean view from $\sim 3$ million years ago. Climate of the Past 16, 1599-1615, https://doi.org/10.5194/cp-16-1599-2020.

McKay, R., Naish, T., Carter, L., Riesselman, C., Dunbar, R., Sjunneskog, C., Winter, D., Sangiorgi, F., Warren, C., Pagani, M., Schouten, S., Willmott, V., Levy, R., DeConto, R., Powell, R.D., 2012. Antarctic and Southern Ocean influences on Late Pliocene global cooling. Proceedings of the National Academy of Sciences 109, 6423-6428, https://doi.org/10.1073/pnas.1112248109.

Mucina, L., Rutherford, M.C., 2006. The Vegetation of South Africa, Lesotho and Swaziland. South African National Biodiversity Institute.

Nelson, G., Hutchings, L., 1983. The Benguela upwelling area. Progress in Oceanography 12, 333-356, http://dx.doi.org/10.1016/0079-6611(83)90013-7. 
872 Pagani, M., Liu, Z., LaRiviere, J., Ravelo, A.C., 2010. High Earth-system climate sensitivity determined from Pliocene carbon dioxide concentrations. Nature Geoscience 3, 27-30, https://doi.org/10.1038/ngeo724.

875 Paillard, D., Labeyrie, L., Yiou, P., 1996. AnalySeries 1.0: a Macintosh software for the analysis of geophysical time-series. Eos 77, 379 .

Peeters, F.J.C., Acheson, R., Brummer, G.-J.A., de Ruijter, W.P.M., Schneider, R.R., Ganssen, G.M., Ufkes, E., Kroon, D., 2004. Vigorous exchange between the Indian and Atlantic oceans at the end of the past five glacial periods. Nature 430, 661-665, http://dx.doi.org/10.1038/nature02785.

Petrick, B., McClymont, E.L., Felder, S., Rueda, G., Leng, M.J., Rosell-Melé, A., 2015. Late Pliocene upwelling in the Southern Benguela region. Palaeogeography, Palaeoclimatology, Palaeoecology 429 , $62-71$ https://doi.org/10.1016/j.palaeo.2015.03.042.

Petrick, B., McClymont, E.L., Littler, K., Rosell-Melé, A., Clarkson, M.O., Maslin, M., Röhl, U., 886 Shevenell, A.E., Pancost, R.D., 2018. Oceanographic and climatic evolution of the southeastern subtropical Atlantic over the last 3.5 Ma. Earth and Planetary Science Letters 492, 12-21, https://doi.org/10.1016/j.epsl.2018.03.054.

Petschick, R., Kuhn, G., Gingele, F., 1996. Clay mineral distribution in surface sediments of 890 the South Atlantic: sources, transport, and relation to oceanography. Marine Geology 130, 203-229, https://doi.org/10.1016/0025-3227(95)00148-4.

Pichevin, L., Cremer, M., Giraudeau, J., Bertrand, P., 2005. A 190 ky record of lithogenic grainsize on the Namibian slope: Forging a tight link between past wind-strength and coastal upwelling dynamics. Marine Geology 218, 81-96, https://doi.org/10.1016/j.margeo.2005.04.003.

896 Prell, W.L., 1984. Covariance Patterns of Foraminiferal 8180: An Evaluation of Pliocene Ice 897 Volume Changes Near 3.2 Million Years Ago. Science 226, 692-694, https://doi.org/10.1126/science.226.4675.692. 
899

900

901

902

903

904

905

906

907

908

909

910

911

912

913

914

915

916

917

918

919

920

921

922

923

924

925

926

Prescott, C.L., Dolan, A.M., Haywood, A.M., Hunter, S.J., Tindall, J.C., 2018. Regional climate and vegetation response to orbital forcing within the mid-Pliocene Warm Period: A study using HadCM3. Global and Planetary Change 161, 231-243, https://doi.org/10.1016/j.gloplacha.2017.12.015.

Prospero, J., 1981. Aeolian transport to the world ocean, in: Emiliani, C. (Ed.), The sea, vol. 7, The oceanic lithosphere. Wiley Interscience, New York, pp. 801-874.

Quick, L.J., Chase, B.M., Wündsch, M., Kirsten, K.L., Chevalier, M., Mäusbacher, R., Meadows, M.E., Haberzettl, T., 2018. A high-resolution record of Holocene climate and vegetation dynamics from the southern Cape coast of South Africa: pollen and microcharcoal evidence from Eilandvlei. Journal of Quaternary Science 33, 487-500, https://doi.org/10.1002/jqs.3028.

Raymo, M.E., Grant, B., Horowitz, M., Rau, G.H., 1996. Mid-Pliocene warmth: stronger greenhouse and stronger conveyor. Marine Micropaleontology 27, 313-326, https://doi.org/10.1016/0377-8398(95)00048-8.

Raymo, M.E., Mitrovica, J.X., O'Leary, M.J., DeConto, R.M., Hearty, P.J., 2011. Departures from eustasy in Pliocene sea-level records. Nature Geoscience 4, 328-332, https://doi.org/10.1038/ngeo1118.

Rind, D., Chandler, M., 1991. Increased ocean heat transports and warmer climate. Journal of Geophysical Research: Atmospheres

96, 7437-7461. https://doi.org/10.1029/91jd00009.

Rommerskirchen, F., Condon, T., Mollenhauer, G., Dupont, L., Schefuss, E., 2011. Miocene to Pliocene development of surface and subsurface temperatures in the Benguela Current system. Paleoceanography 26, https://doi.org/10.1029/2010pa002074.

Rosell-Melé, A., Martínez-Garcia, A., McClymont, E.L., 2014. Persistent warmth across the Benguela upwelling system during the Pliocene epoch. Earth and Planetary Science Letters 386, 10-20, https://doi.org/10.1016/j.epsl.2013.10.041.

Rossignol, M., 1962. Analyse pollinique de sédiments marins quaternaires en Israël II. Sédiments pleistocènes. Pollen et Spores 4, 121-148. 
927 Routson, C.C., McKay, N.P., Kaufman, D.S., Erb, M.P., Goosse, H., Shuman, B.N., Rodysill,

928

929

930

931

932

933

934

935

936

937

938

939

940

941

942

943

944

945

946

947

948

949

950

951

952

953

954 J.R., Ault, T., 2019. Mid-latitude net precipitation decreased with Arctic warming during the Holocene. Nature 568, 83-87, https://doi.org/10.1038/s41586-019-1060-3.

Salzmann, U., Haywood, A.M., Lunt, D.J., Valdes, P.J., Hill, D.J., 2008. A new global biome reconstruction and data-model comparison for the Middle Pliocene. Global Ecology and Biogeography 17, 432-447, https://doi.org/10.1111/j.1466-8238.2008.00381.x.

Schulz, M., Mudelsee, M., 2002. REDFIT: estimating red-noise spectra directly from unevenly spaced paleoclimatic time series. Computers \& Geosciences 28, 421-426, https://doi.org/10.1016/S0098-3004(01)00044-9.

Scott, L., 1982. Late Quaternary fossil pollen grains from the Transvaal, South Africa. Review of Palaeobotany and Palynology 36, 241-278, https://doi.org/10.1016/0034$6667(82) 90022-7$.

Scott, L., 1999. Vegetation history and climate in the Savanna biome South Africa since 190,000 ka: a comparison of pollen data from the Tswaing Crater (the Pretoria Saltpan) and Wonderkrater. Quaternary International 57, 215-223, https://doi.org/10.1016/S1040-6182(98)00062-7.

Scott, L., Partridge, T., 1994. Some manifestations of Pliocene warming in southern Africa, in: Thompson, R.S. (Ed.), Pliocene Terrestrial Environments and Data/Model Comparisons. US Geological Survey Open-File Report 94-23, pp. 54-55.

Scott, L., van Zinderen Barker, S.E., 1985. Exotic pollen and long-distance wind dispersal at a sub-Antarctic Island. Grana 24, 45-54. https://doi.org/10.1080/00173138509427422.

Shannon, L.V., Nelson, G., 1996. The Benguela: large scale features and processes and system variability, in: Wefer, G., Berger, W.H., Siedler, G., Webb, D. (Eds.), The South Atlantic: Present and Past Circulation. Springer-Verlag, Berlin Heidelberg, pp. 63-210.

Tankard, A.J., Rogers, J., 1978. Late Cenozoic Palaeoenvironments on the West Coast of Southern Africa. Journal of Biogeography 5, 319-337, https://doi.org/10.2307/3038026.

Tyson, P.D., Preston-Whyte, R.A., 2000. The weather and climate of southern Africa. Oxford University Press, Cape Town. 
Valsecchi, V., Chase, B.M., Slingsby, J.A., Carr, A.S., Quick, L.J., Meadows, M.E., Cheddadi, R., Reimer, P.J., 2013. A high resolution 15,600-year pollen and microcharcoal record from the Cederberg Mountains, South Africa. Palaeogeography, Palaeoclimatology, Palaeoecology 387, 6-16, https://doi.org/10.1016/j.palaeo.2013.07.009.

Van As, J., du Preez, J., Brown, L., Smit, N., 2012. The Story of Life \& the Environment. Penguin Random House South Africa.

Wheeler, A.D., 2010. Impacts of degradation on critically endangered Oudtshoorn Gannaveld. University of the Western Cape, Cape Town, South Africa.

Williams, G.P., Bryan, K., 2006. Ice age winds: An aquaplanet model. Journal of climate 19, 1706-1715, https://doi.org/10.1175/JCLI3766.1.

Woillez, M.-N., Levavasseur, G., Daniau, A.-L., Kageyama, M., Urrego, D., Sánchez-Goñi, M.F., Hanquiez, V., 2014. Impact of precession on the climate, vegetation and fire activity in southern Africa during MIS4. Climate of the Past 10, 1165-1182, https://doi.org/10.5194/cp-10-1165-2014.

Zhao, X., Dupont, L., Meadows, M.E., Wefer, G., 2016a. Pollen distribution in the marine surface sediments of the mudbelt along the west coast of South Africa. Quaternary International 404, 44-56, https://doi.org/10.1016/j.quaint.2015.09.032.

Zhao, X., Dupont, L., Schefuß, E., Meadows, M.E., Hahn, A., Wefer, G., 2016b. Holocene vegetation and climate variability in the winter and summer rainfall zones of South Africa. The Holocene 26, 843-857, https://doi.org/10.1177/0959683615622544. 